

ISSN 2357-9854 | e-ISSN 2596-3198 (online)

\title{
Errar - Partilhar - Aprender \\ O ensino transdisciplinar e holístico através de técnicas das Artes Visuais (experiências em quatro continentes)
}

\author{
Ângela Saldanha \\ (Associação de Professores de Expressão e Comunicação Visual - \\ APECV, Viseu, Portugal) \\ Teresa Torres de Eça \\ (Associação de Professores de Expressão e Comunicação Visual - \\ APECV, Viseu, Portugal)
}

\begin{abstract}
RESUMO - Errar - Partilhar - Aprender. O ensino transdisciplinar e holístico através de técnicas das Artes Visuais (experiências em quatro continentes) - A Viagem como processo de partilha de conhecimento, revela-se, para as autoras, num método de encontro com o Outro. Uma forma de compreensão e de experimentação de práticas educativas, com a utilização de ferramentas inerentes às Artes Visuais (Arte Contemporânea). Neste artigo, são compartilhadas quatro práticas transdisciplinares realizadas em diferentes continentes (Europa - Portugal; Ásia Hong Kong; América - Brasil; África - Nigéria), tendo como base, principalmente, as Walking Pedagogies e exercícios realizados participativamente e colaborativamente entre todos os participantes, tendo em conta o meio onde se encontram.
\end{abstract}

PALAVRAS - CHAVE

Viagem. Walking Pedagogies. Ensino formal e informal. Transdisciplinaridade. Arte Contemporânea.

ABSTRACT - Straggle - Share - Learn. Transdisciplinary and holistic teaching through Visual Arts techniques (experiences in four countries) - The travelling as a process of sharing knowledge, is revealed, for the authors, in a method of meeting with the Other. A way of understanding and experimenting with educational practices, using tools inherent to Visual Arts (Contemporary Art). In this article, four transdisciplinary practices on different continents are shared (Europe - Portugal; Asia - Hong Kong; America - Brazil; Africa - Nigeria), based mainly on the Walking Pedagogies and participatory exercises performed collaboratively among all participants, taking into account the environment in which they find themselves.

\section{KEYWORDS}

Travelling. Walking Pedagogies. Formal and informal education. Transdisciplinarity. Contemporary art.

RESUMEN - Errar - Compartir - Aprender. La enseñanza transdisciplinaria y holística a través de técnicas de artes visuales (experiencias en cuatro continentes) - El viaje como un proceso de intercambio de conocimientos se revela, para los autores, en un método de encuentro con el Otro. Una forma de entender y experimentar con las prácticas educativas, utilizando herramientas inherentes a las Artes Visuales (Arte Contemporáneo). En este artículo, se comparten cuatro prácticas transdisciplinarias realizadas en diferentes continentes (Europa - Portugal; Asia Hong Kong; América - Brasil; África - Nigeria), basadas principalmente en Pedagogías a pie y ejercicios realizados de manera participativa y colaborativa entre todos los participantes, teniendo en cuenta su entorno.

\section{PALABRAS CLAVE}

Viaje. Pedagogías del camiñante. Educación formal e informal. Transdisciplinariedad. Arte Contemporáneo. 




\section{Introdução}

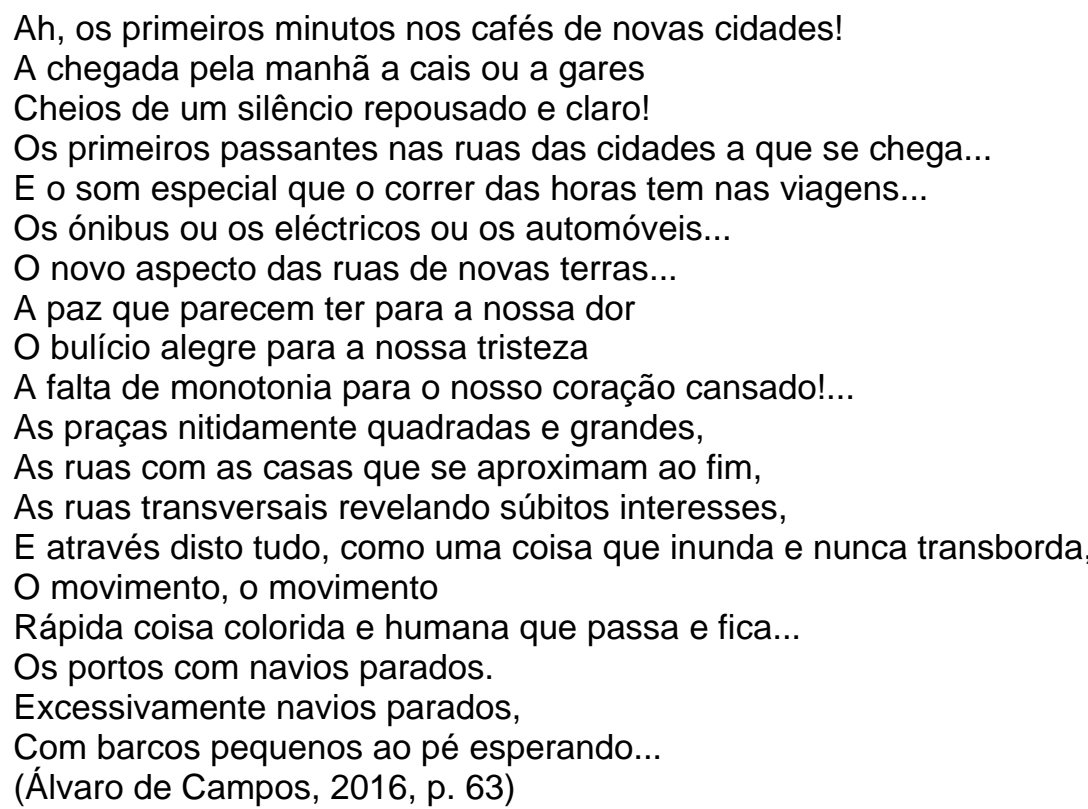

Viajar, para nós, é um processo introspetivo de/no conhecimento. Uma ampliação da deambulação pela Ágora grega, de forma a vislumbrar e provar o mundo.

Muitos autores (CARERI, 1996; BRETON, 1952; DEBORD, 1955; entre outros) defendem que o Ser Humano só evoluiu porque Errou, porque o processo de errância, de procura e caminho, o conduziu a novos lugares, experiências e sensações, que não eram possíveis na permanência do seu corpo num só lugar. Assim, vemos o processo de aprendizagem, só potenciamos as nossas capacidades no movimento, na capacidade de fazer perguntas, de experimentar, unir disciplinas/conhecimentos e errar.

Esta busca, por novas significâncias, diferentes paradigmas ou âmagos das questões, fazem-nos mover entre lugares distintos, em buscar de experiências e partilhas com o outro diferente (tão igual a nós).

Um conhecimento efetivo e afetivo sobre/no lugar, com práticas coletivas, educativas e de trocas. Numa democrática consciência da importância de cada 


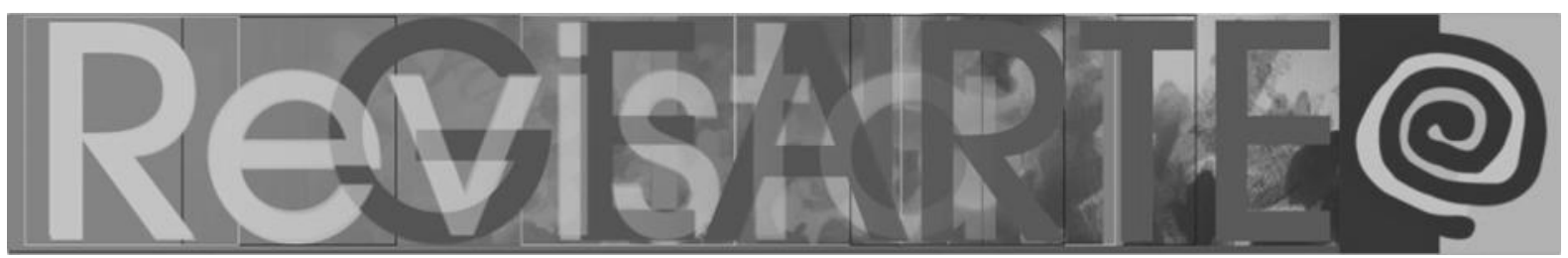

um, onde somos todos companheiros da mesma viagem, e onde, não existem muros que distinguem estados económicos, sociais ou culturais, mas privilegiam a singularidade, com as suas especificidades e a sua forma de comunicar.

Identificamo-nos com o "delirium ambulatorium" defendido por Hélio Oiticica (1978) pela errância pelos "vazios plenos" (referidos pelos artistas Lygia Clark e Hélio Oiticica, anos 60) e pelos objetivos artivistas (MOURÃO, 2014).

Por isso, realizamos partilhas em diferentes continentes, com pessoas de diferentes faixas etárias, segundo uma pesquisa de investigação-ação, a/r/tográfica, cartográfica, walking pedagogies e de construção de conhecimento no/com o colectivo/lugar, a partir de práticas experimentais artísticas pedagógicas, em comunidade formais (espaços educativos, por exemplo: escolas ou congressos/seminários) ou informais (comunidades locais) que potenciam a comunicação, a troca e respeito pelas culturas e intensificam o valor do indivíduo no reforço da importância da sua voz na educação coletiva. Uma educação diversificada e inclusiva, com a tentativa constante de respeitar as dinâmicas próprias de cada lugar.

Aqui, faremos um relato de algumas dessas experiências, sustentadas no lugar onde se realizam - com referência a outras - , em lugares de quatro países, de quatro continentes, escolhidos por ordem cronológica, onde a imagem tem o mesmo poder que a palavra, procurando uma narrativa - pessoal - mais holística sobre o ocorrido.

Re-examine all you have been told at school or church or in any book, dismiss whatever insults your own soul, and your very flesh shall be a great poem and have the richest fluency not only in its words but in the silent lines of its lips and face and between the lashes of your eyes and in every motion and joint of your body. (SMITH, 2016, p. XXIII).

\section{Portugal (Europa)}

Vivemos e nascemos em Portugal. 


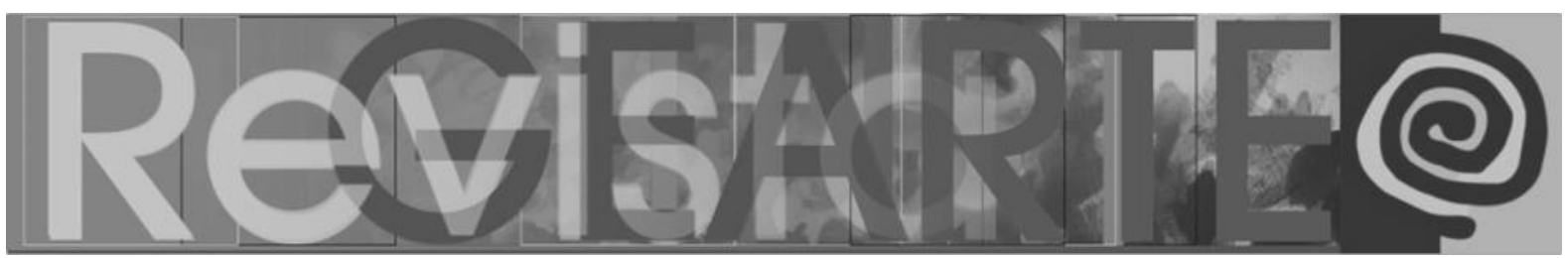

A nossa formação na área das Artes e da Educação e as nossas demandas profissionais e sociais aproximam-nos, inevitavelmente, desta realidade.

Conhecemos bem o currículo, as escolas, os debates sociais e as dificuldades/oportunidades/valências deste país, daí que o nosso relato, neste caso, possa se centrar numa crítica mais depurada e manifestamente mais sensível.

O Ensino do 1. ciclo ( 6 aos 10 anos de idade) é o mais frágil e aquele que consideramos dos mais importante para o desenvolvimento das bases criadoras, psicológicas e produtoras.

Depois de uma Educação Pré-Escolar (dos 3 aos 6 anos), de fundações construtivistas criativas e de trabalho em equipa, surge uma formatação e programação restrita e catalisadora de ações, numa pedagogia unicelular, individualista e com conteúdos pouco centrados nas relações interpessoais, culturais, inclusivas, ou que possam motivar o gosto pelo conhecimento do mundo.

Escolhemos, por estas razões, esta faixa etária, para realizar um trabalho, juntamente com outros dois artistas (Estrella Luna - México e Ícaro Pintor Portugal) em três escolas do país (litoral norte, interior centro e interior sul), no ano letivo de 2015-2016.

Apesar de ter sido um trabalho realizado durante vários meses, parte de um projeto maior (Projeto "CREARTE", financiado pela União Europeia), onde se pretende a inserção da Arte Contemporânea nas escolas do $1 .^{\circ}$ ciclo, com a presença de artistas.

In this workshop we will create together some strategies that could be used in contemporary artistic practices in schools and communities. We will create in a creative way how to generate active participation and collaborative work and working with social aspects, urban, experiences and collective places of memory. (citação dos artistas do projeto - Ângela Saldanha, Estrella Luna e Ícaro Pintor - 2015) 


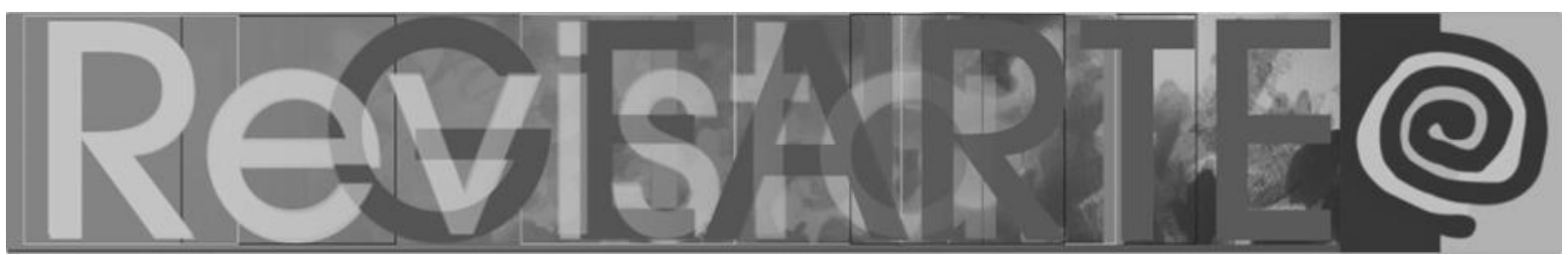

Aqui, só descreveremos a parte inicial (de preparação), centrada no conhecimento do entorno (abordagem transdisciplinar), desenvolvida e preparada para a realidade portuguesa da educação, nesta faixa etária, pois, como refere Careri (2013, p. 27-28): "Uma vez satisfeitas as exigências primárias, o caminhar transformou-se numa fórmula simbólica que tem permitido que o homem habite 0 mundo. (...) A partir dessa simples ação foram desenvolvidas as mais importantes relações que o homem travou com o território".

Through different activities that was building with the students like the "Derive", the mail art made of ceramic, animation, making scenarios and theatrical dramatization, was created an participative construction of all the actors in the context, with the artists, the students, the educative and the community.

Dialoguing together, we discovered about what is contemporary art for each one, in the way to intended the creation of a different concept of Museum, a traveling place of the work produced and exchange of experiences; narrowing relations between communities that can be perpetuated in other joint actions. (citação dos artistas do projeto - Ângela Saldanha, Estrella Luna e Ícaro Pintor - 2015)

Figura 1 - Exemplo de dinâmica realizada numa escola de 1. Ciclo com o envolvimento do corpo e do entendimento das suas interações - o jogo da cabra cega

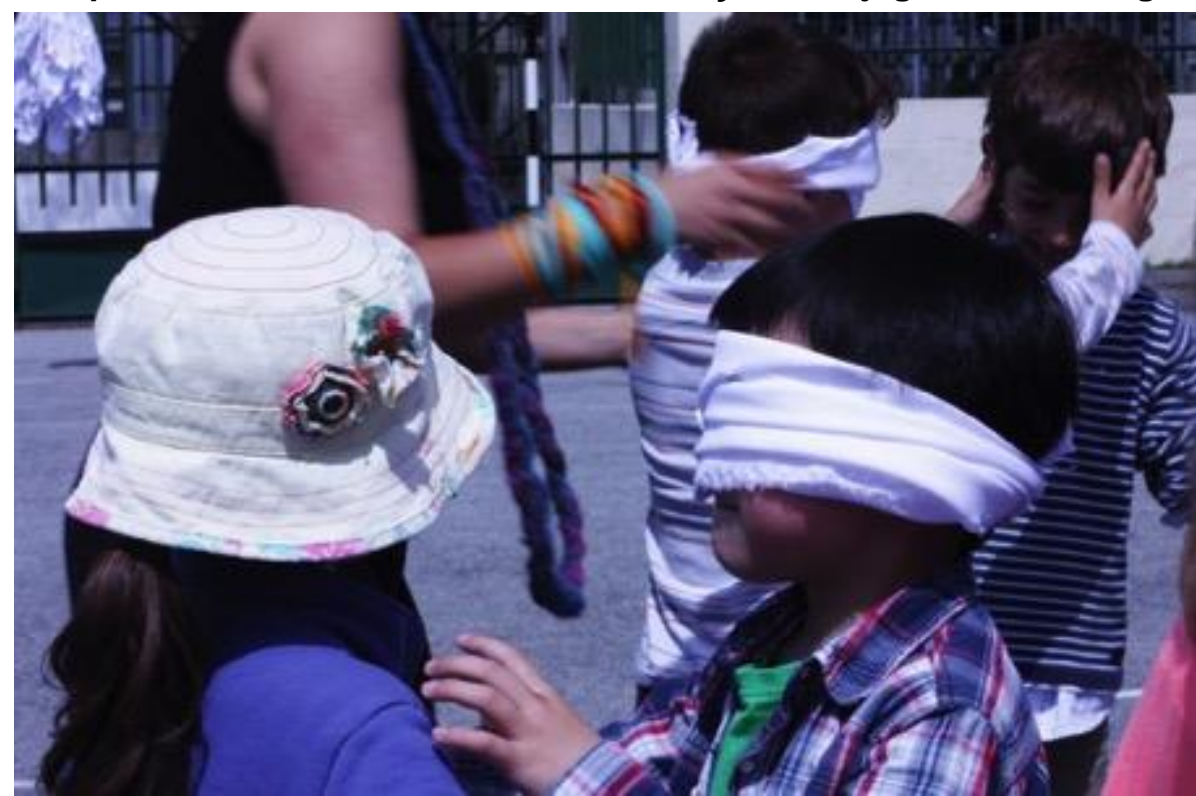

Fonte: Fotografia dos artistas do projeto CREARTE.

Intelligence and learning are strictly linked to the social and physical environment, the child learns through doing and actively creating. Also the social influence, the experimentation and the creation that exist in the first stages are essential for your human development (Jean Piaget, Theory of

SALDANHA, Ângela; EÇA, Teresa Torres de. Errar - Partilhar - Aprender. O ensino transdisciplinar 287 e holístico através de técnicas das Artes Visuais (experiências em quatro continentes).

Revista GEARTE, Porto Alegre, v. 7, n. 2, p. 283-315, maio/ago. 2020

Disponível em: http://seer.ufrgs.br/gearte 
cognitive development). (citação dos artistas do projeto - Ângela Saldanha, Estrella Luna e Ícaro Pintor - 2015)

Figura 2 - Exemplo de dinâmica realizada numa escola de 1.․ Ciclo com o conceito de Deriva

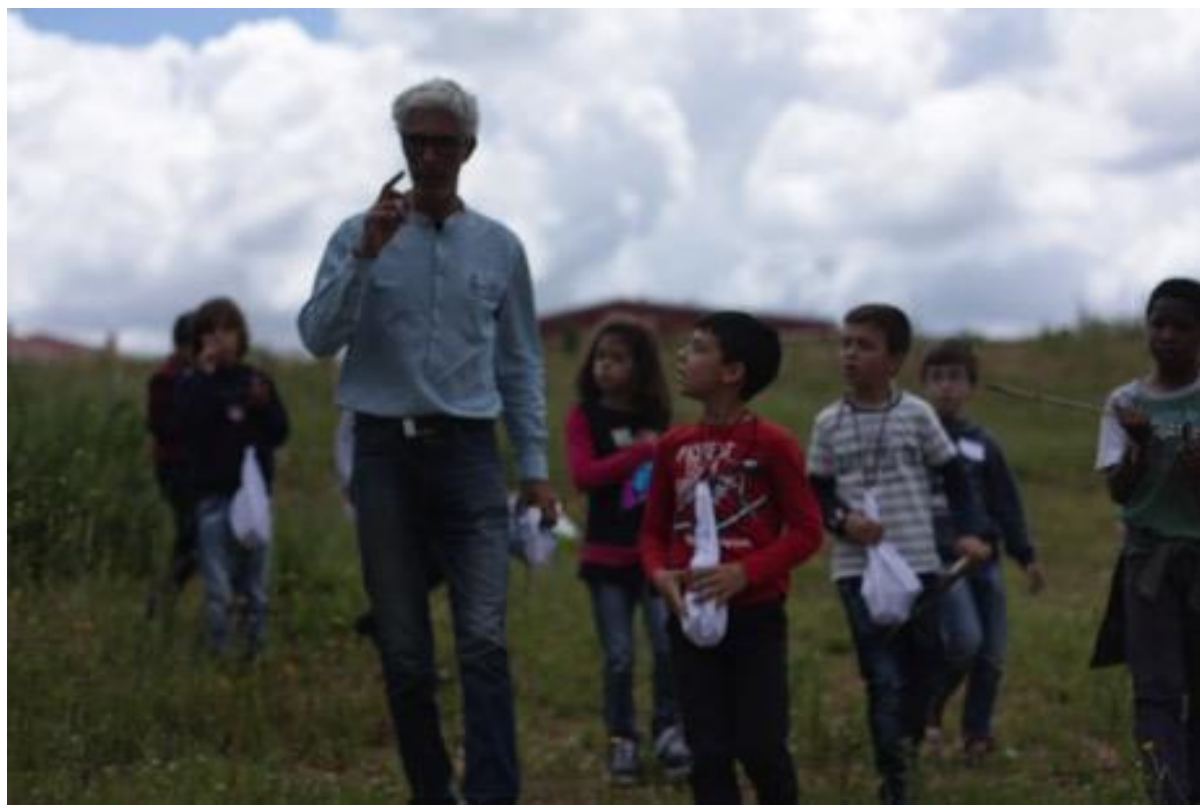

Fonte: Fotografia dos artistas do projeto CREARTE.

Another aspect that is implemented in these dynamics is the work with the members of the community of the school or educational center where it is intervened.

As can be seen in many of the artistic pieces of contemporary art, these emerge within a specific context, full of networks of connection between people, stories, traditions and customs. In this way it is sought in turn to observe with the children these connections that are in their community and thus experiment and create with them and their environment. (citação dos artistas do projeto - Ângela Saldanha, Estrella Luna e Ícaro Pintor - 2015) 


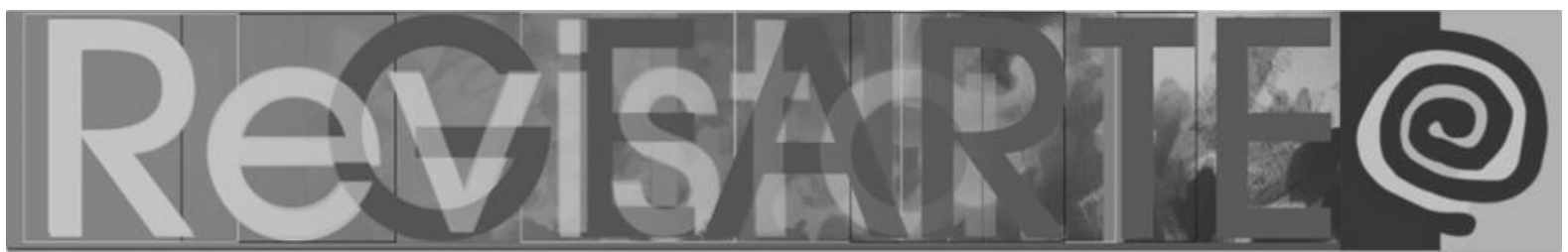

Figura 3 - Exemplo do material recolhido na deriva, posteriormente utilizado como ferramentas para a realização de trabalhos

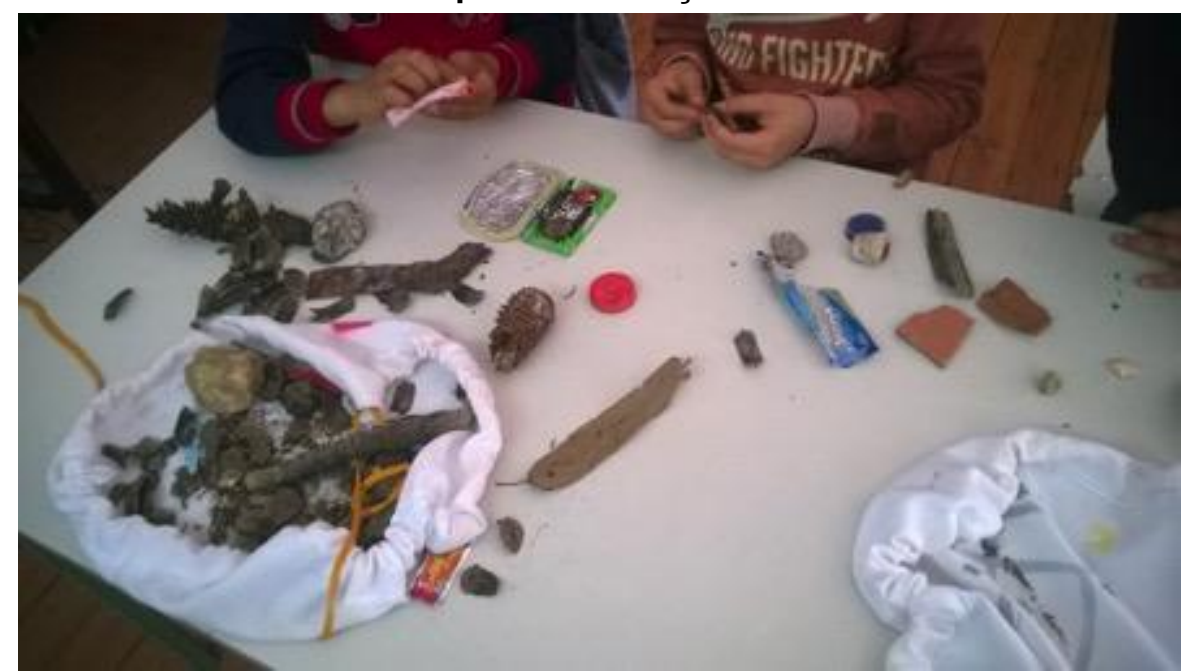

Fonte: Fotografia dos artistas do projeto CREARTE.

An example of this we have some dynamics where from the dialogue and the exploration of our space are potentialities for the children's imagination. (citação dos artistas do projeto - Ângela Saldanha, Estrella Luna e Ícaro Pintor - 2015)

Figura 4 - Imagem captada na exploração do meio



Fonte: Fotografia dos artistas do projeto CREARTE.

Com este trabalho interdisciplinar, que se revelou transdisciplinar, podemos, entre outros objetivos: 


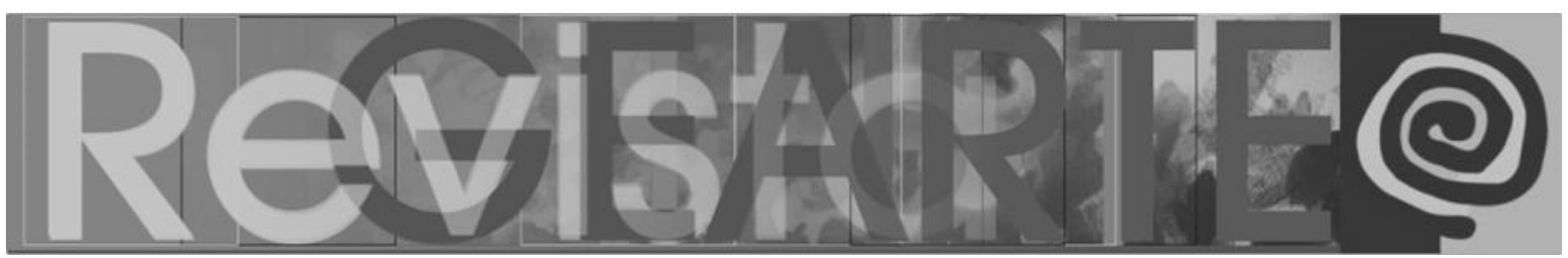

- Gerar participação ativa e o trabalho colaborativo;

- Realizar uma interação coletiva entre os alunos, professores, pais, integrantes da comunidade;

- Criar conhecimentos partilhados;

- Estimular a reflexão e criação de propostas por parte dos alunos;

- Desenvolver a criatividade e um pensamento divergente;

- Desenvolver um trabalho com técnicas interdisciplinares e utilização de novas ferramentas do entorno quotidiano.

\section{Hong Kong (Ásia)}

No final de 2018, viajamos até Hong Kong, uma região administrativa especial (RAE) da República Popular da China (RPC).

A sua população de oito milhões de pessoas (semelhante à população de Portugal), centrada numa área reduzida, rodeada de arranha-céus, primorosamente vigiados, fizeram-nos questionar o espaço onde deambulávamos. Para nós, tudo parecia um gigante Centro Comercial: com pessoas apressadas, músicas natalícias (fruto das vanguardas capitalistas), cheiros apetitosos e cores radiantes. 


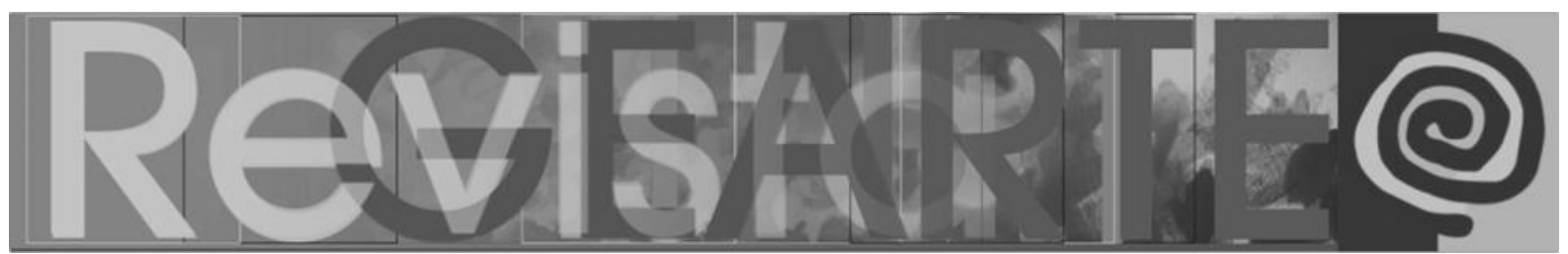

Figura 5 - Fotografia captada no percurso das autoras pela cidade

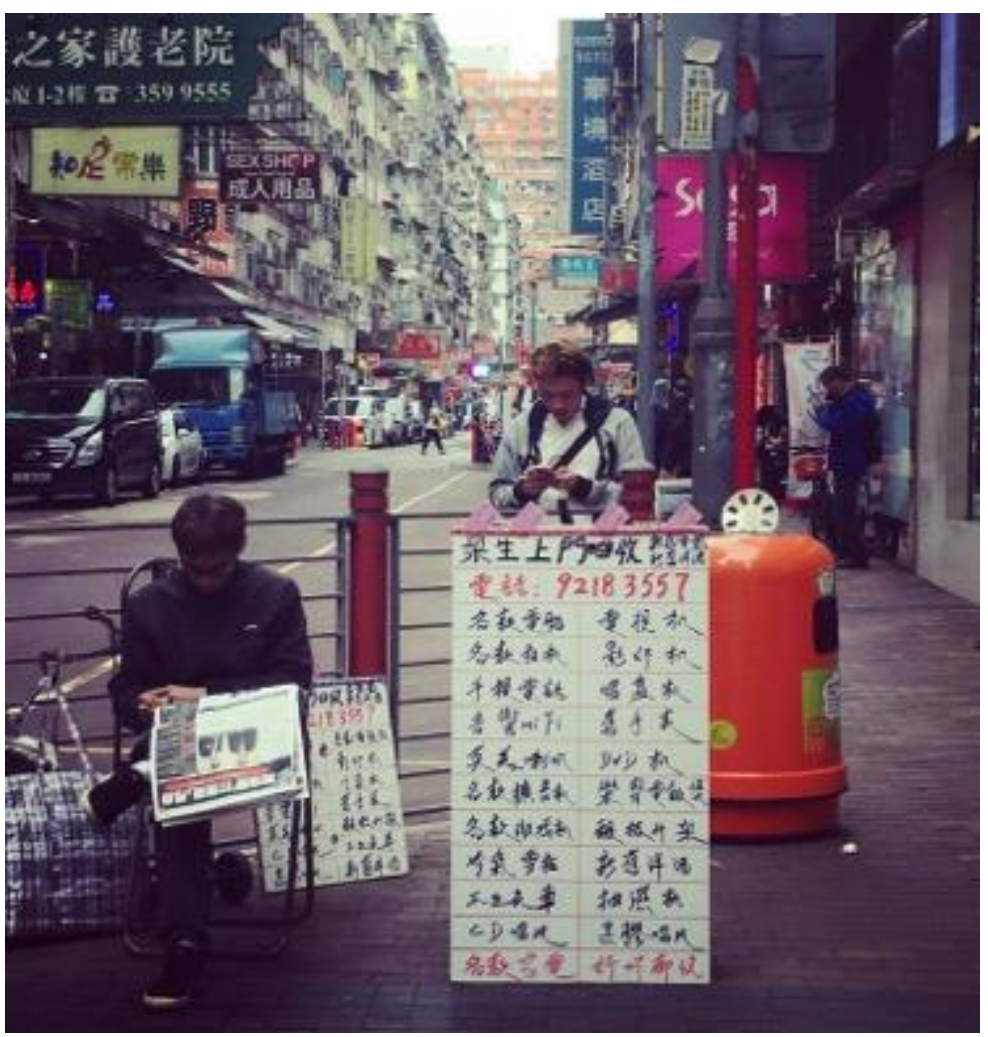

Fonte: Fotografia das autoras.

Figura 6 - Fotografia captada no percurso das autoras pela cidade

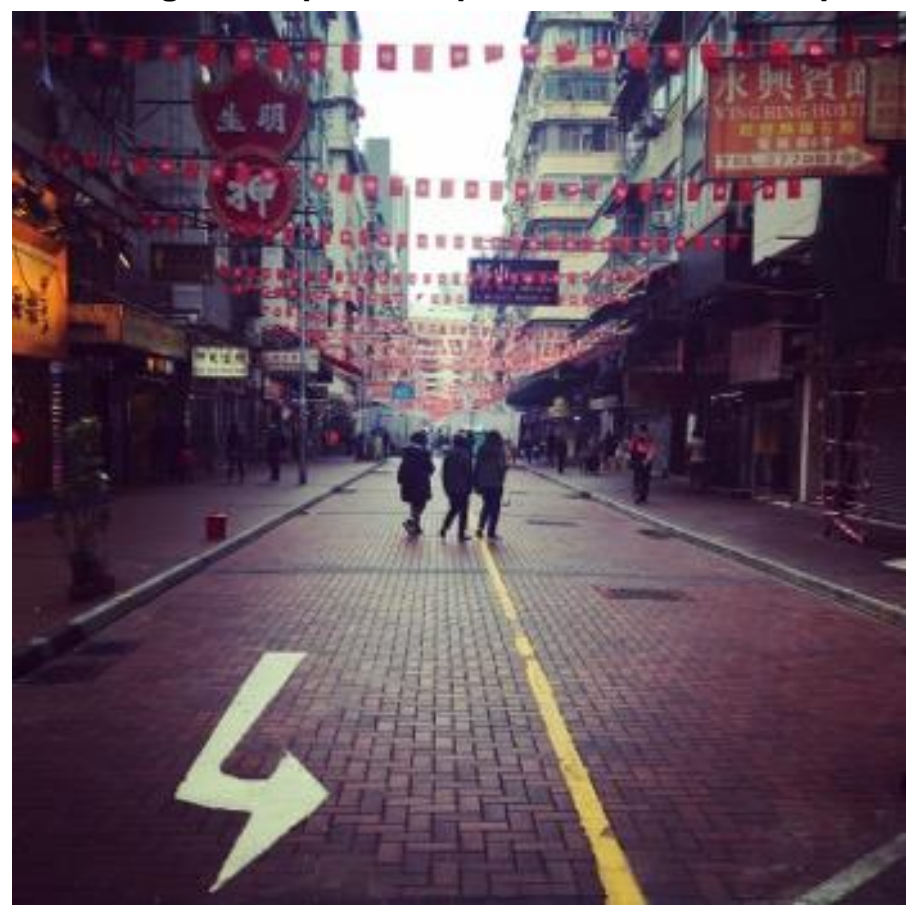

Fonte: Fotografia das autoras.

SALDANHA, Ângela; EÇA, Teresa Torres de. Errar - Partilhar - Aprender. O ensino transdisciplinar e holístico através de técnicas das Artes Visuais (experiências em quatro continentes).

Revista GEARTE, Porto Alegre, v. 7, n. 2, p. 283-315, maio/ago. 2020.

Disponível em: http://seer.ufrgs.br/gearte 


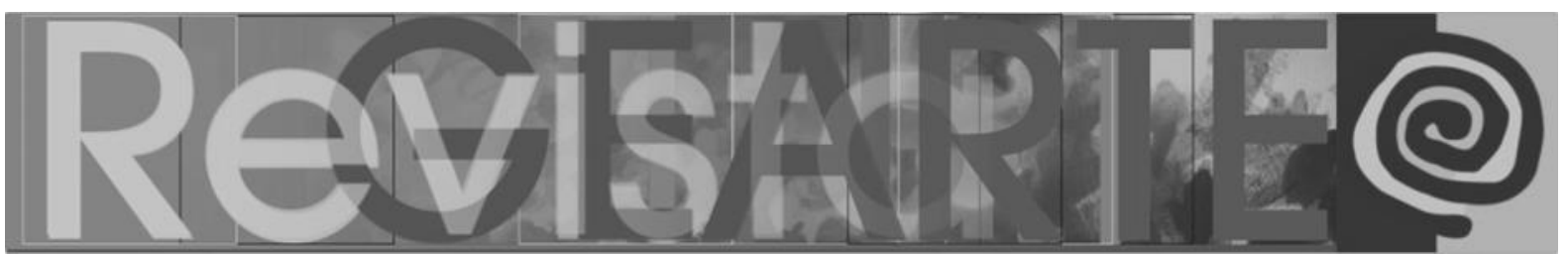

Figura 7 - Fotografia captada no percurso das autoras pela cidade

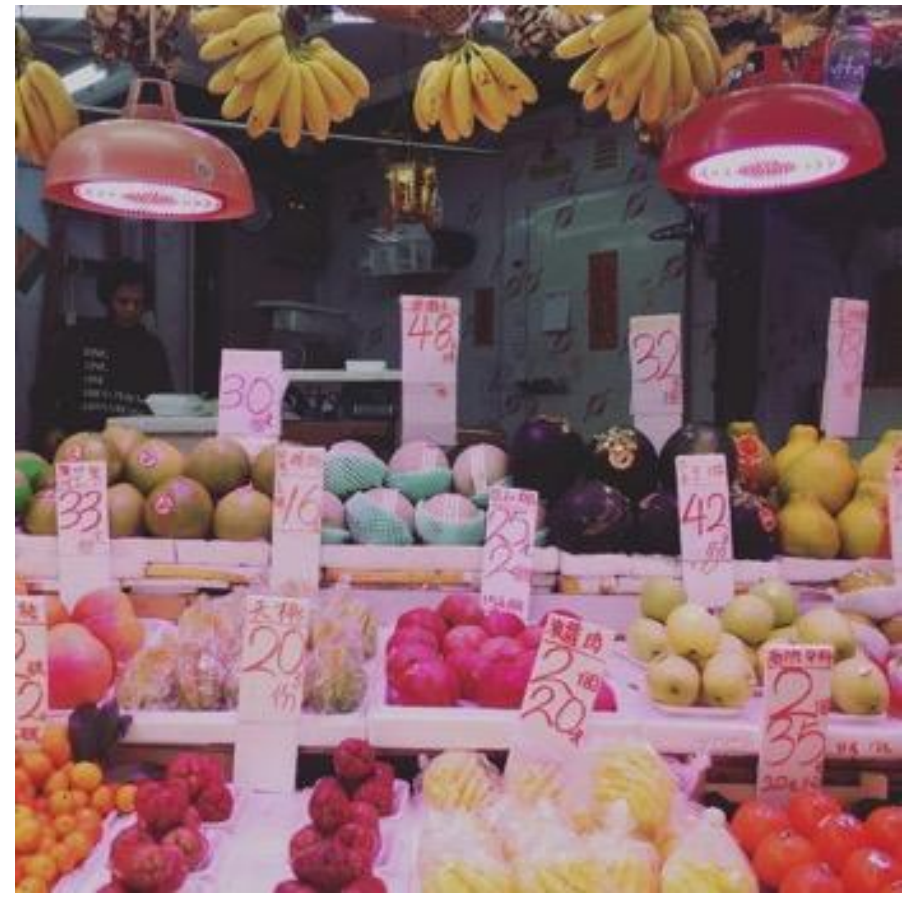

Fonte: Fotografia das autoras.

mote para a deslocação foi o congresso regional asiático da $\operatorname{InSEA}^{1}$

(International Society for Education through Art), realizado na Universidade de

Educação de Hong Kong, onde tivemos a oportunidade de realizar a oficina

"Cartographies" com várias faixas etárias.

\begin{abstract}
Summary:
As researchers and activists in art education we use art-based research methods. In this article we will present some of our methods based on walking pedagogies and theories of psychogeography invented by surrealists and artists from the Situationist International group. These artistic process help to investigate phenomena and to create theories as an alternative way of knowing that informs the researcher. Through ways of Walking we engage in ethnographic practices by exploring and testing out new pedagogies.

The article begins with a brief approach to some research methodologies based on the arts and design, given that they are specific methodologies in the field of art and art education, as Tom Barone (2008) pointed out are not substitutes for quantitative methods or qualitative methods; are different ways of seeing and opening the way to knowledge (Eisner, 1991). The article then focuses on the concept of travel and walking as a drift and research cartography. The third part highlights some navigational
\end{abstract}

1 InSEA Asia Regional Congress, 2018, Hong Kong \& 7th World Chinese Art Education Symposium, https://www.insea.org 


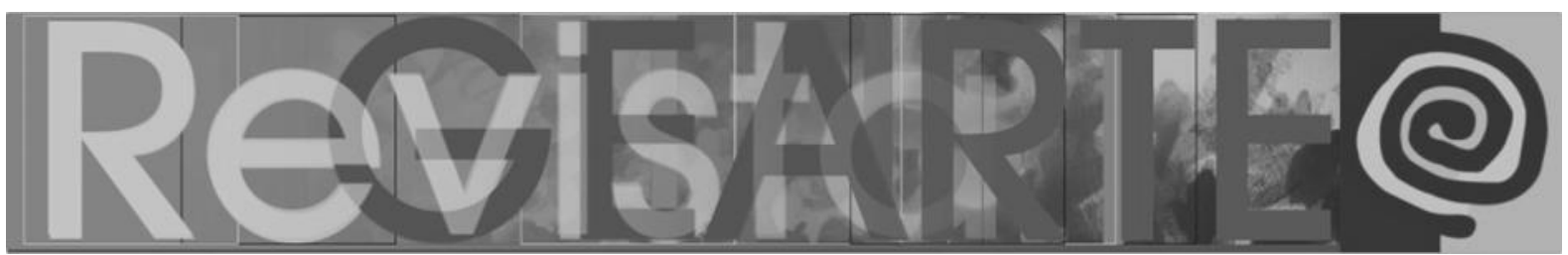

instruments related to the artistic process and then opens up the various possibilities of walking pedagogies and cartography.

Key Words:

arts-based research; dérive, walking, cartography, art

(Hong Kong, InSEA Asia Regional Congress, 2018, Hong Kong \& 7th World Chinese Art Education Symposium; "Challenges and Transformations")

Partindo das bases desenvolvidas e defendidas pelo grupo Internacional Situacionista (1956-57), da Psicogeografia: "Estudo dos efeitos precisos do meio geográfico, conscientemente organizado ou não, que atuam diretamente no comportamento afetivo dos indivíduos." (Anônimo, 1958 in CARERI, 2013, p. 90), trabalharam-se, nesta oficina, as memórias das deambulações realizadas pelos participantes. Cartografias, recheadas de significados e trocas significativas das vivências de cada um.

Figura 8 - Início da Oficina: Experiência sensorial com recurso a música e a evocações de lugares

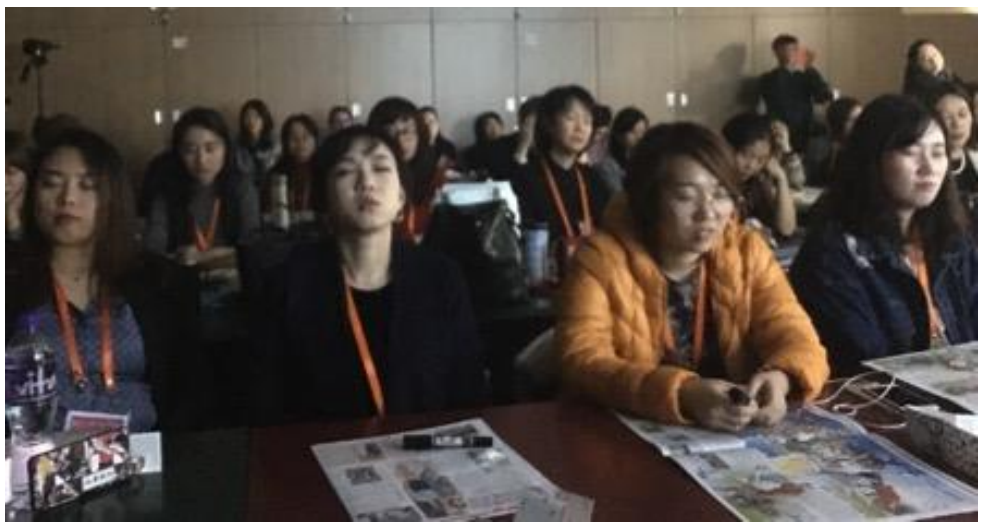

Fonte: Fotografia das autoras.

Figura 9 - Construção das Cartografias

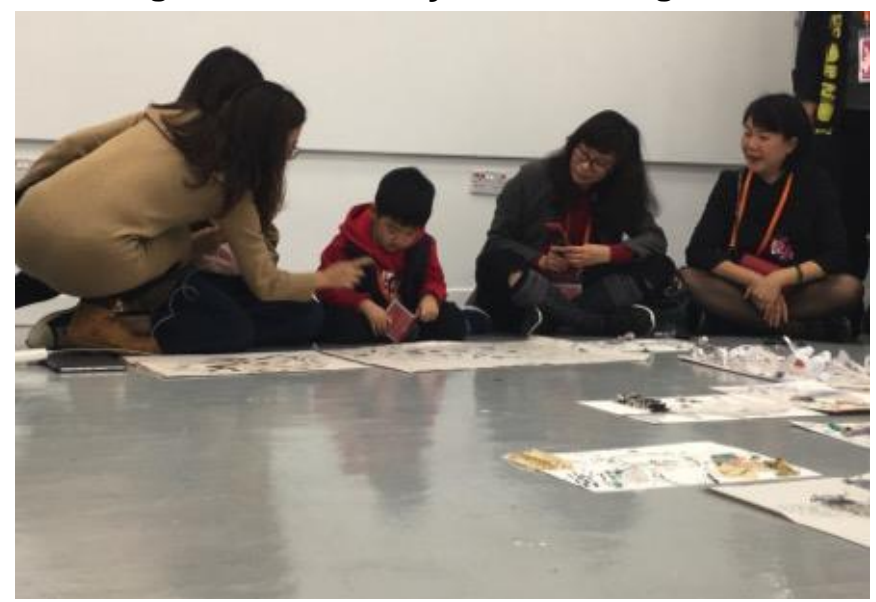

Fonte: Fotografia das autoras.

SALDANHA, Ângela; EÇA, Teresa Torres de. Errar - Partilhar - Aprender. O ensino transdisciplinar e holístico através de técnicas das Artes Visuais (experiências em quatro continentes).

Revista GEARTE, Porto Alegre, v. 7, n. 2, p. 283-315, maio/ago. 2020.

Disponível em: http://seer.ufrgs.br/gearte 


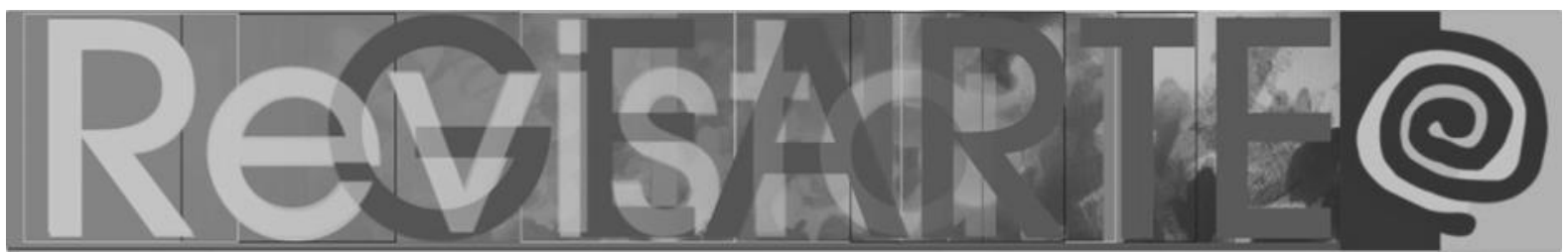

Figura 10 - Apresentação das cartografias

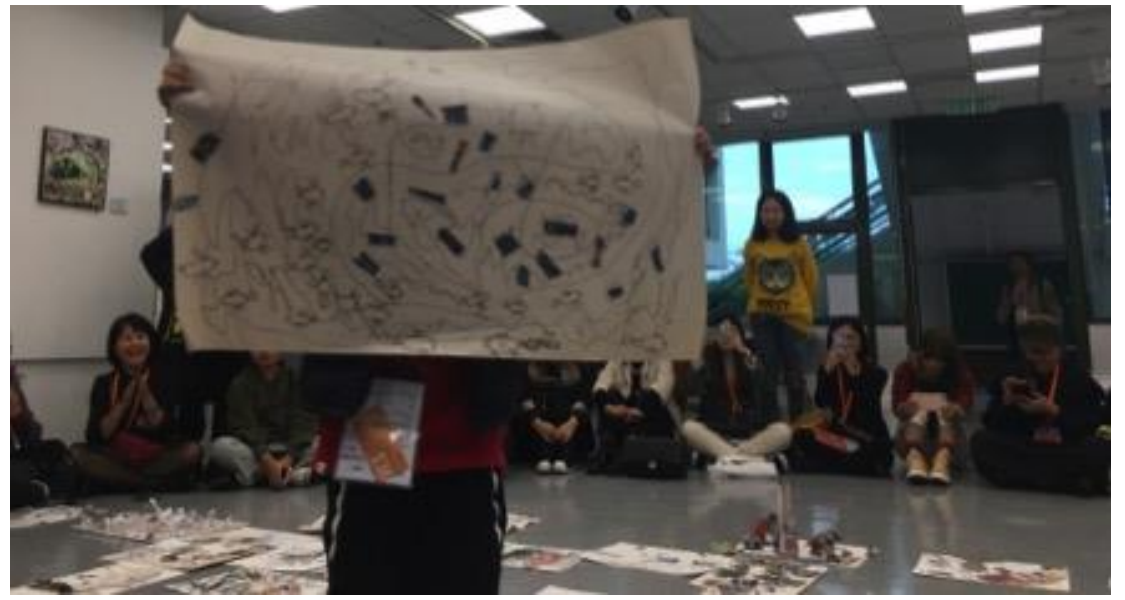

Fonte: Fotografia das autoras.

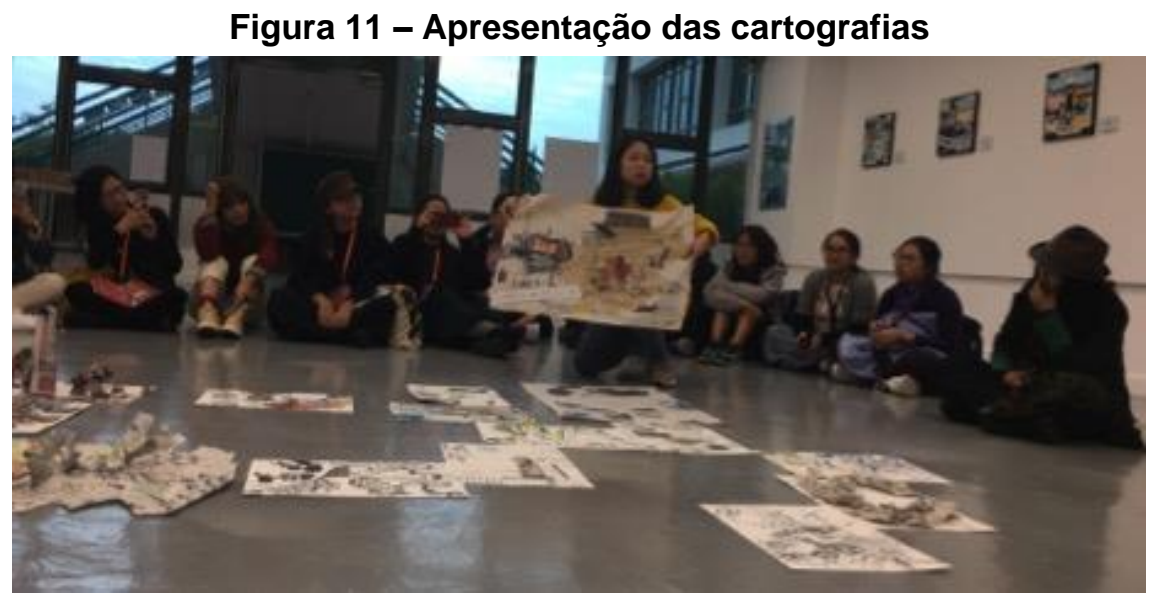

Fonte: Fotografia das autoras.

Figura 12 - Apresentação das cartografias

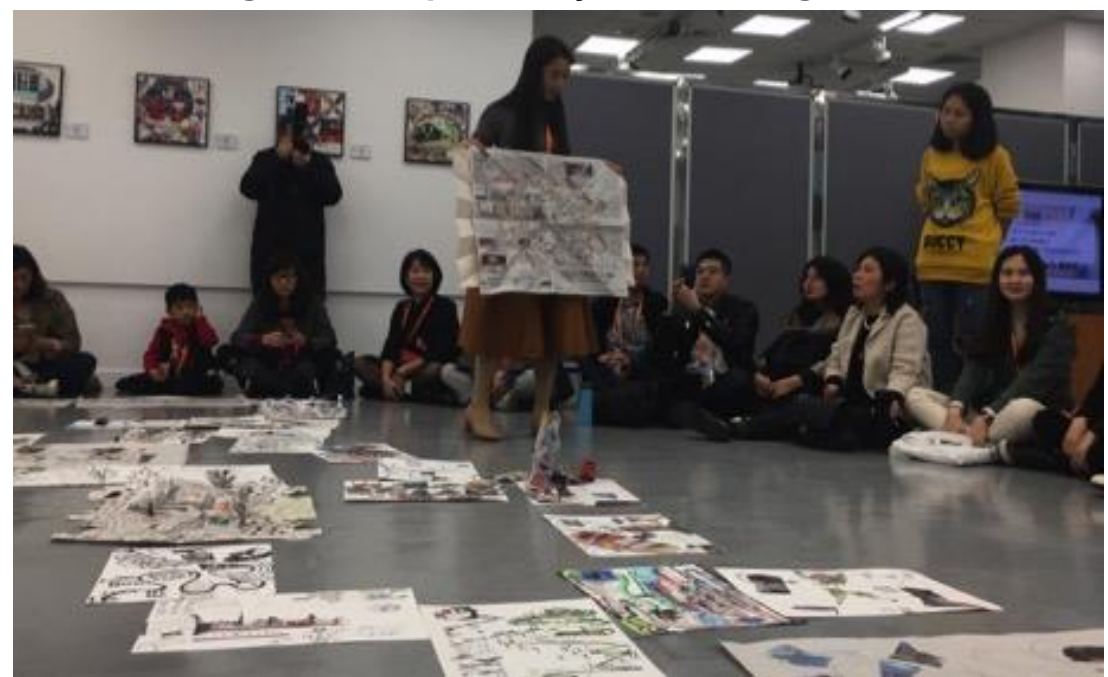

Fonte: Fotografia das autoras.

SALDANHA, Ângela; EÇA, Teresa Torres de. Errar - Partilhar - Aprender. O ensino transdisciplinar e holístico através de técnicas das Artes Visuais (experiências em quatro continentes).

Revista GEARTE, Porto Alegre, v. 7, n. 2, p. 283-315, maio/ago. 2020.

Disponível em: http://seer.ufrgs.br/gearte 


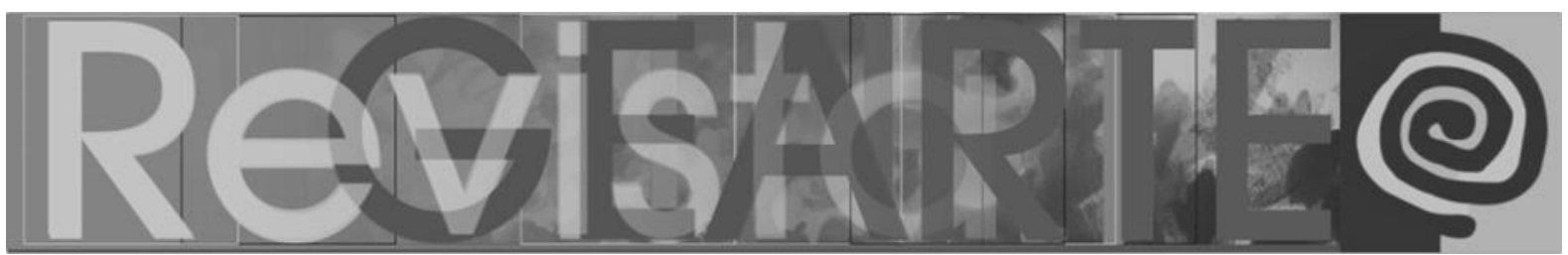

Nesta atividade, com utilização de colagens, de desenho e da música, foram muitas as partilhas sensíveis que podemos apreender, como:

- A facilidade adquirida, pelos mais novos, de compreender a interdisciplinaridade dos exercícios propostos;

- O respeito pelo lugar do outro e pela simbologia partilhada;

- A curiosidade e entusiasmo na realização de novas experiências;

- A representação, maioritariamente sensitiva (pouco figurativa), dos caminhos quotidianos;

- O receio da partilha ou de cometer erros;

- A aceitação/compreensão da experiência sem muitos questionamentos.

\section{Brasil (América)}

Nosso conhecimento não era de estudar em livros.

Era de pegar de apalpar de ouvir e de outros sentidos.

Seria um saber primordial?

Nossas palavras se ajuntavam uma na outra por amor

e não por sintaxe.

A gente queria $\mathrm{o}$ arpejo. $\mathrm{O}$ canto. $\mathrm{O}$ gorjeio das palavras.

Um dia tentamos até de fazer um cruzamento de árvores com passarinhos

para obter gorjeios em nossas palavras.

Não obtivemos.

Estamos esperando até hoje.

Mas bem ficamos sabendo que é também das percepções primárias que nascem arpejos e canções e gorjeios.

Porém naquela altura a gente gostava mais das palavras desbocadas.

Tipo assim: Eu queria pegar na bunda do vento.

O pai disse que vento não tem bunda.

Pelo que ficamos frustrados.

Mas o pai apoiava a nossa maneira de desver o mundo que era a nossa maneira de sair do enfado.

A gente não gostava de explicar as imagens porque explicar afasta as falas da imaginação.

A gente gostava dos sentidos desarticulados como a conversa dos passarinhos no chão a comer pedaços de mosca.

Certas visões não significavam nada mas eram passeios verbais.

A gente sempre queria dar brazão às borboletas.

A gente gostava bem das vadiações com as palavras do que das prisões gramaticais.

Quando o menino disse que queria passar para as palavras suas peraltagens até os caracóis apoiaram.

A gente se encostava na tarde como se a tarde fosse um poste. 


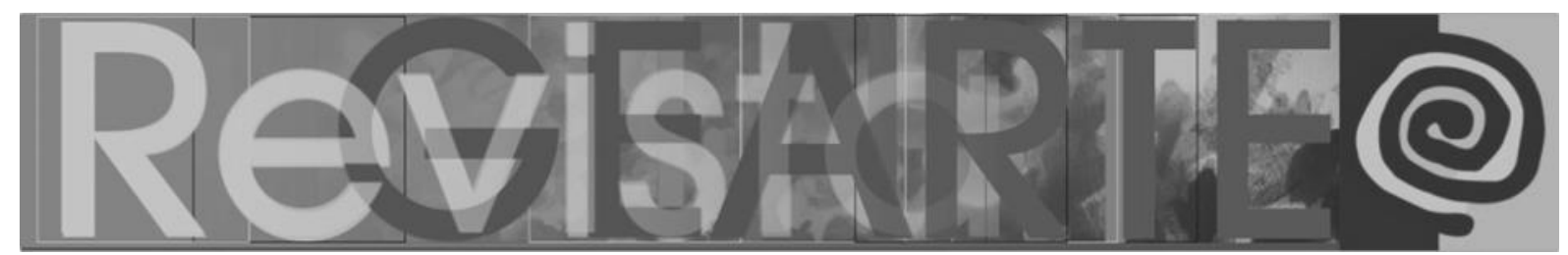

A gente gostava das palavras quando elas perturbavam os sentidos normais da fala.

Esses meninos faziam parte do arrebol como os passarinhos.

(Barros, 2016, p.430)

O Brasil é um país de tamanho continental e não conseguimos ficar indiferentes à sua diversidade cultural. Pela singularidade da experiência, escolhemos para este artigo, uma prática realizada na Floresta da Amazónia, na zona de Santarém, com a tribo Munduruku, em Abril de 2019.

\section{Figura 13 - Povos originários na reivindicação dos seus direitos, Brasília, maio de 2019}

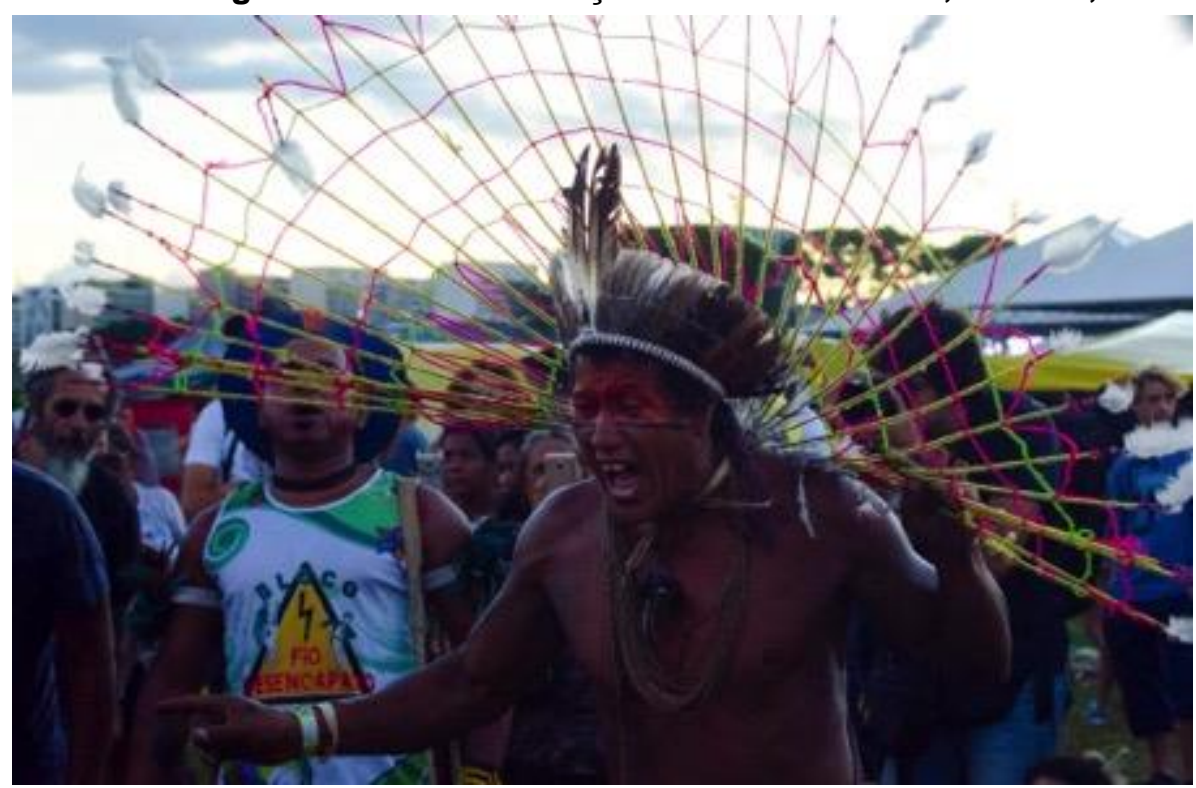

Fonte: Fotografia das autoras.

Distante das corridas capitalistas das grandes cidades, a tribo Munduruku vive no meio da floresta, aprendendo com ela, sem conseguirmos, aqueles que a visitam, diferenciar aquele que ocupa ou o que é ocupado. A harmonia é de uma beleza tão grande que nos sentimos, imediatamente, emocionalmente exacerbados. 


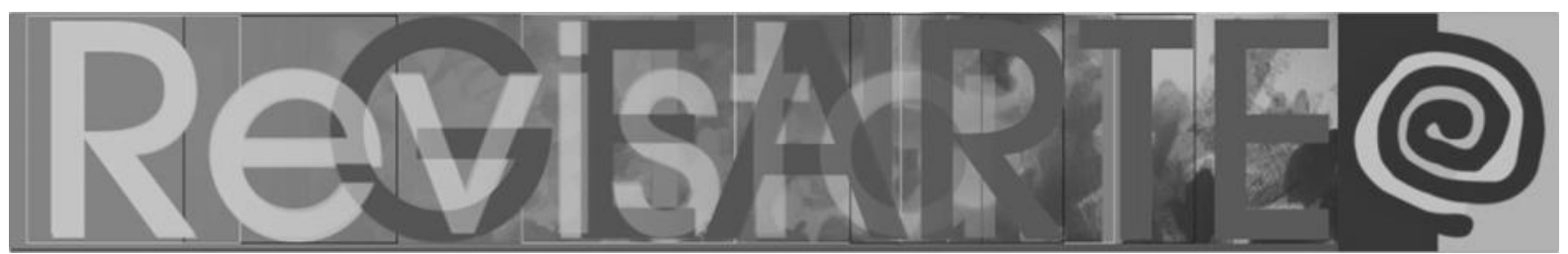

Figura 14 - Amazônia



Fonte: Fotografia das autoras.

Figura 15 - Cacique da Tribo Munduruku na Floresta Amazônia

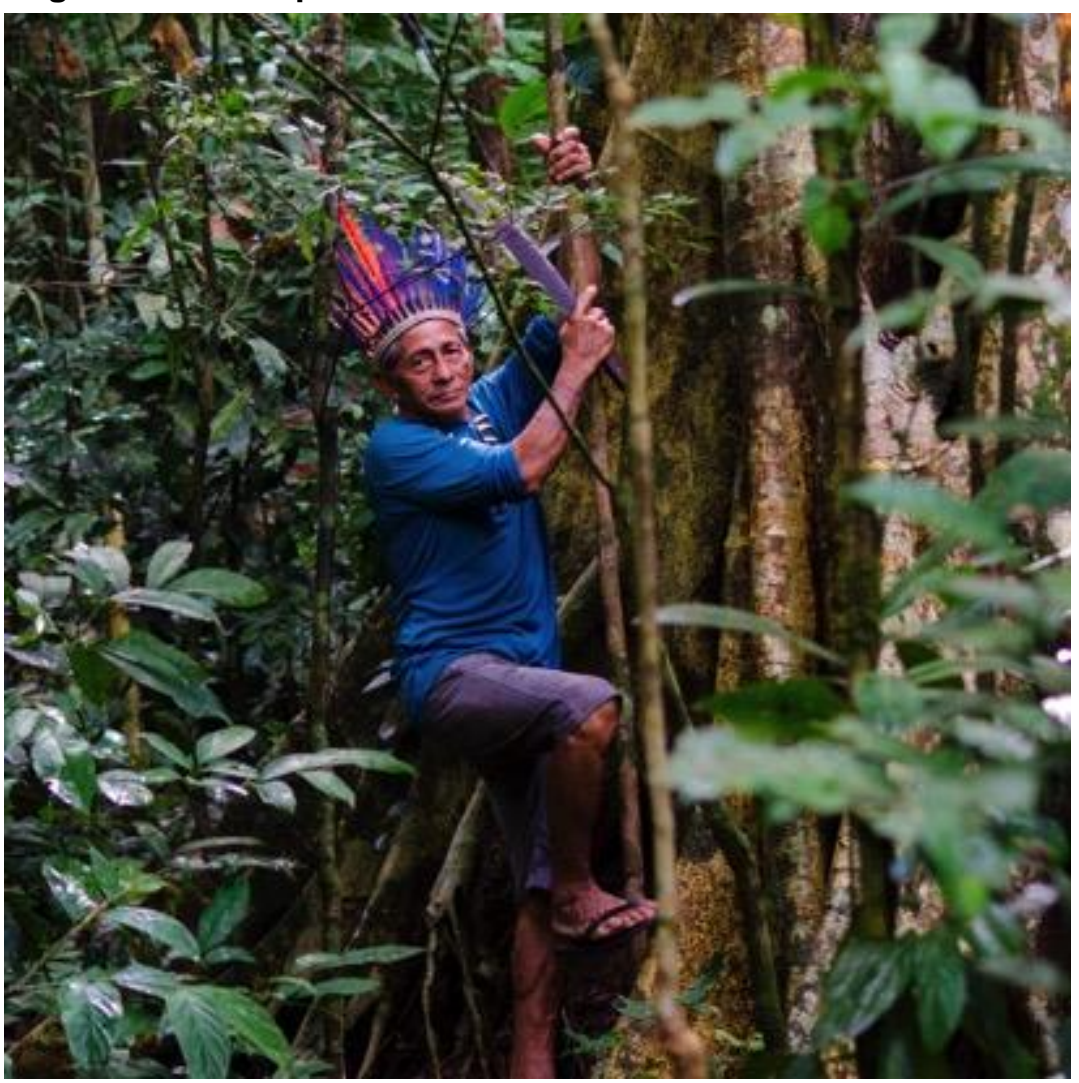

Fonte: Fotografia das autoras.

SALDANHA, Ângela; EÇA, Teresa Torres de. Errar - Partilhar - Aprender. O ensino transdisciplinar e holístico através de técnicas das Artes Visuais (experiências em quatro continentes).

Revista GEARTE, Porto Alegre, v. 7, n. 2, p. 283-315, maio/ago. 2020.

Disponível em: http://seer.ufrgs.br/gearte 


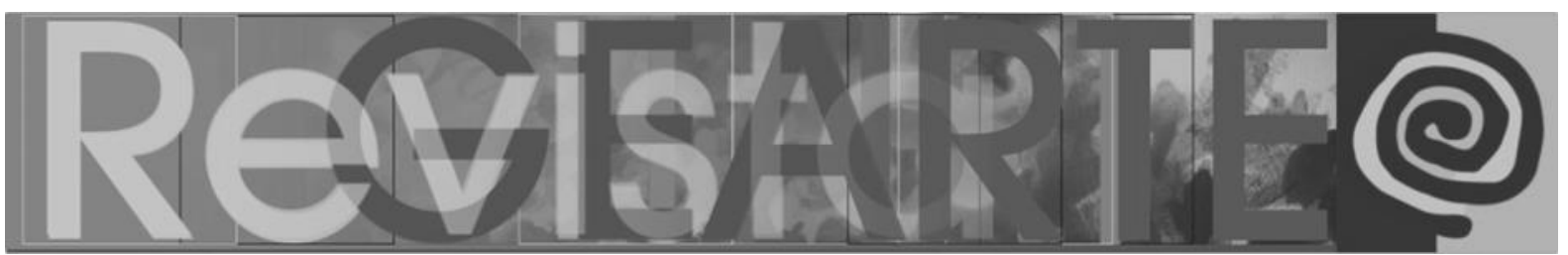

Figura 16 - Criança da tribo Munduruku

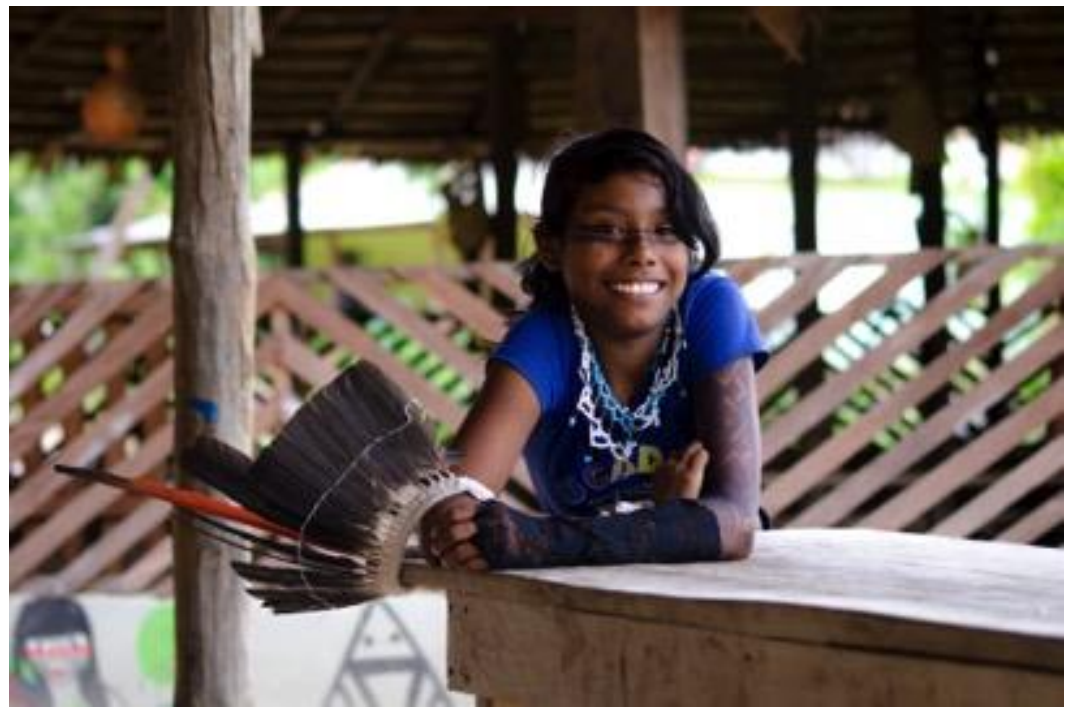

Fonte: Fotografia das autoras.

Deambular, toma aqui, um significado mais consciente e rico. Um ecossistema feito de trocas mediadas, reflectidas e ostentosamente simbólicas.

\footnotetext{
Amazónia, abril-maio de 2019

Como escrever quando ainda não existem palavras para tudo o que vejo ou sinto?

Descalça, na terra que não conheço, conecto-me com a ancestralidade do mundo.

Lugares, bem diferentes do espaço onde habito, contam-me histórias.

Estórias de bichos: rastejantes, voadores, caminhantes... todos

humanos. Extremamente humanos.

Absorvo tudo, sofregamente.

Quero conectar-me. Voltar ao princípio, à essência.

A água cai. As aranhas já o sabiam e tecem, em conversa com os homens.

Estes constroem as suas casas no mesmo lugar.

- "Qual a razão de escolherem este espaço para a vossa casa, como sabem onde chega a água no tempo das chuvas?"

- "Olha para as aranhas. Elas ensinam-nos. Elas sabem-no."

Teço palavras e encontro razões desconhecidas.

Ouço: Palavras de ordem! (Palavras sem sons e Sons sem palavras).

Tudo se completa.

As formigas mostram-nos os caminhos seguros, deixam rastos para os primeiros desenhos. Mapas cartográficos, que as crianças conhecem tão bem.

Borboletas majestosas que permitem o sonho.

Conecto-me com o outro lado do oceano e volto à pergunta de partida:

Não existem palavras, porque aqui elas nunca foram precisas. E, no nosso intimo, entendemos isso tão bem.
} 


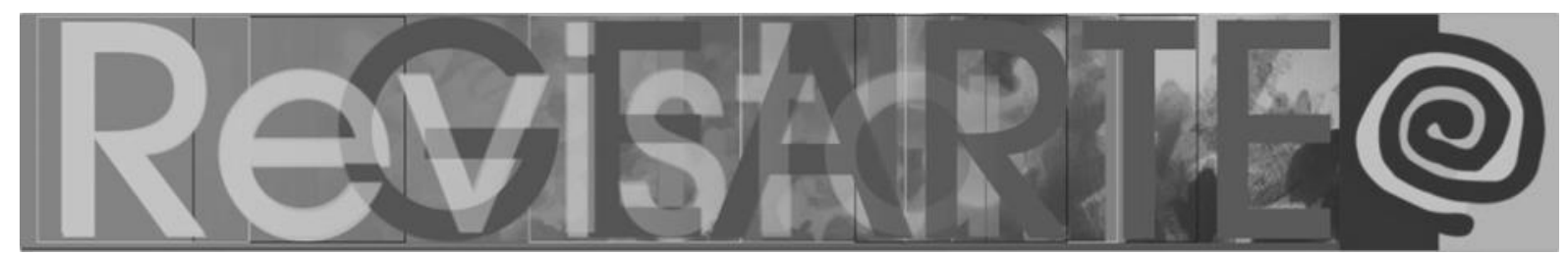

Preciso de guardar os mapas. Conexões que as imagens não contam sozinhas e onde nunca necessitamos de palavras. Amuletos, respostas aos nossos cartões de visita.

A floresta e aqueles que nela habitam não reconhecem a ortodoxia ocidental dos mundos além mares.

Amuletos Nomina: mapa da ancestralidade, cartão de visita, caminhos percorridos, aquilo que levo comigo e que me lembram, continuamente, onde estive e o que aprendi.

Bordo rastos ou rituais (não sei). Fecho a folha A4 nela mesma. Nunca mais poderá ser aberta.

Mapas cruzados prontos a novas narrativas, a novas viagens...

(registos no Diário de Bordo de uma das autoras deste artigo)

\section{Figura 17 - Captações da Floresta Amazónia}

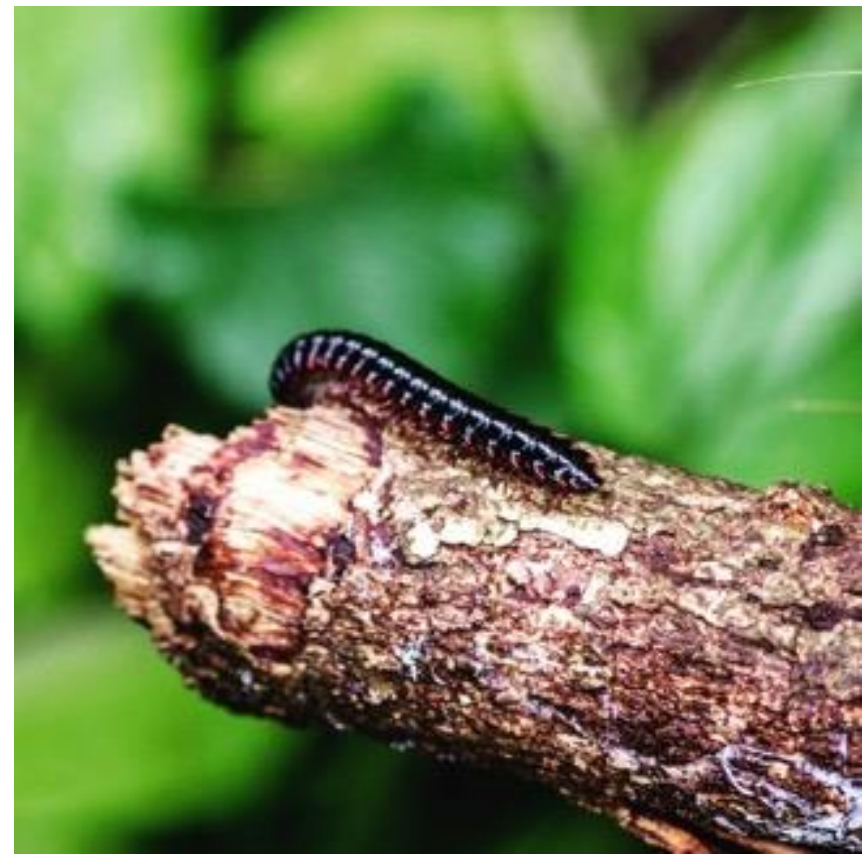

Fonte: Fotografia das autoras.

A Partilha iniciou com a doação de cartões de visita realizados numa aula de Metodologias no Colégio das Artes, da Universidade de Coimbra - Portugal, como elo de ligação entre duas comunidades distintas, mas que se querem conhecer e apoiar. 


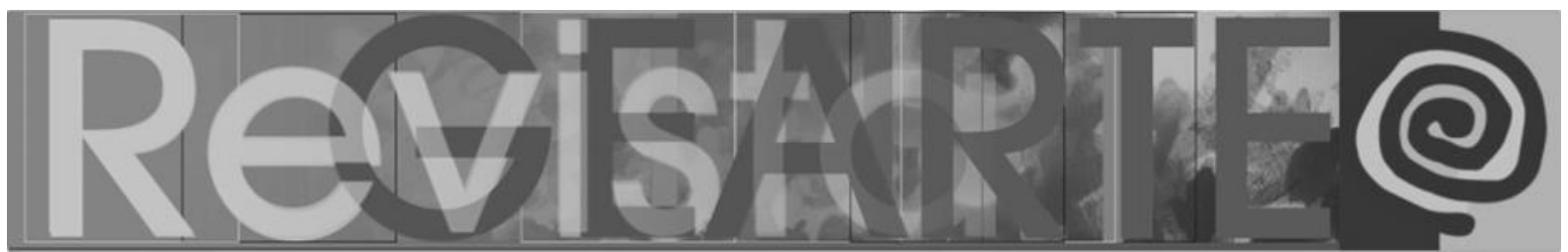

Figura 18 - Realização dos cartões de visita - Colégio das Artes, Coimbra, Portugal

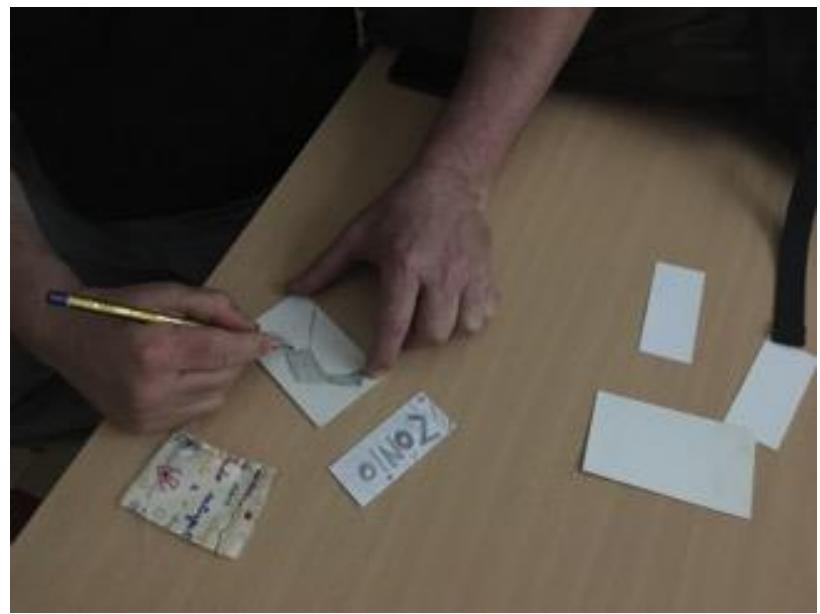

Fonte: Fotografia das autoras.

Figura 19 - Realização dos cartões de visita - Colégio das Artes, Coimbra, Portugal

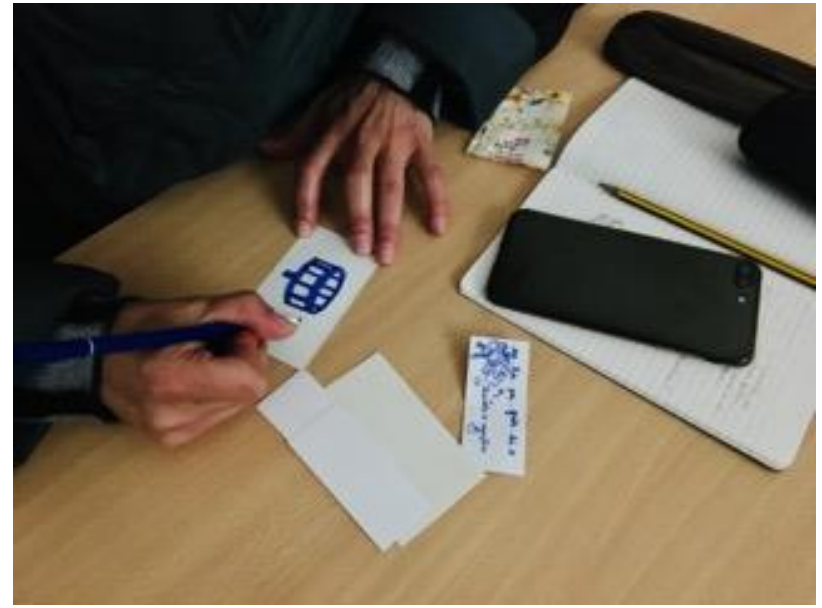

Fonte: Fotografia das autoras.

Figura 20 - Realização dos cartões de visita - Colégio das Artes, Coimbra, Portugal

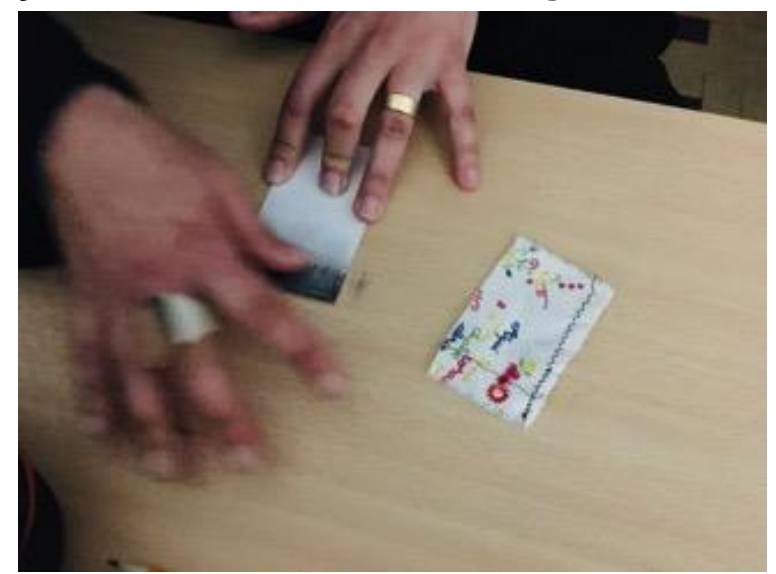

Fonte: Fotografia das autoras.

SALDANHA, Ângela; EÇA, Teresa Torres de. Errar - Partilhar - Aprender. O ensino transdisciplinar e holístico através de técnicas das Artes Visuais (experiências em quatro continentes).

Revista GEARTE, Porto Alegre, v. 7, n. 2, p. 283-315, maio/ago. 2020.

Disponível em: http://seer.ufrgs.br/gearte 


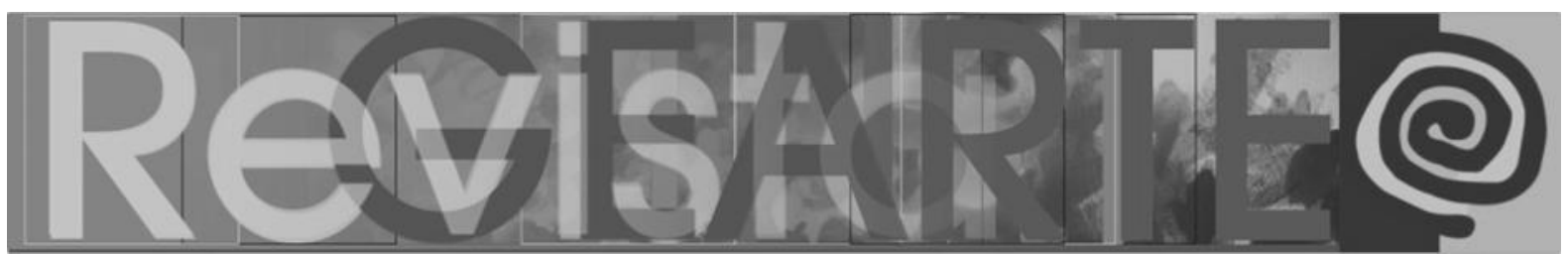

Figura 21 - Realização dos cartões de visita - Colégio das Artes, Coimbra, Portugal

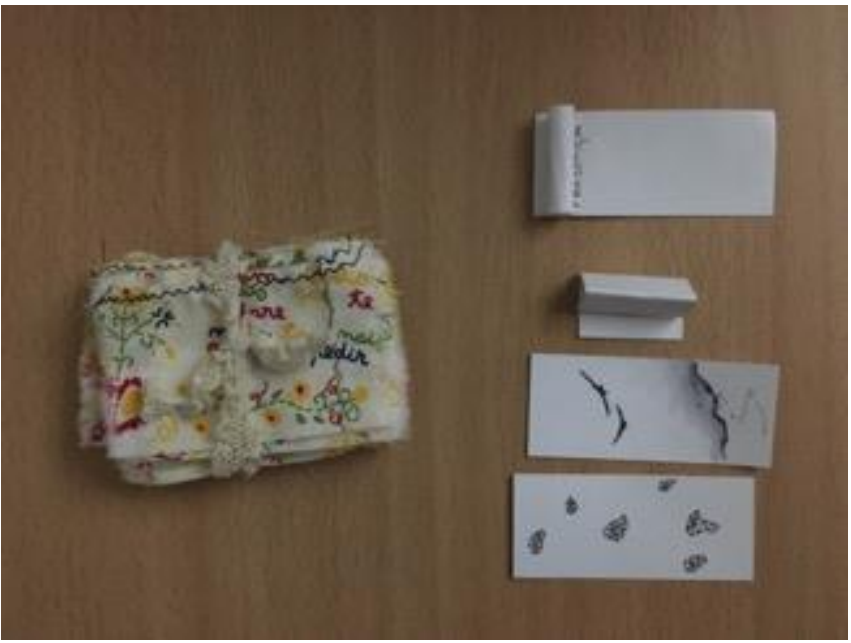

Fonte: Fotografia das autoras.

Figura 22 - Os cartões de visita, embrulhados em tecidos tradicionais portugueses Lenços dos Namorados - que falam de Amor

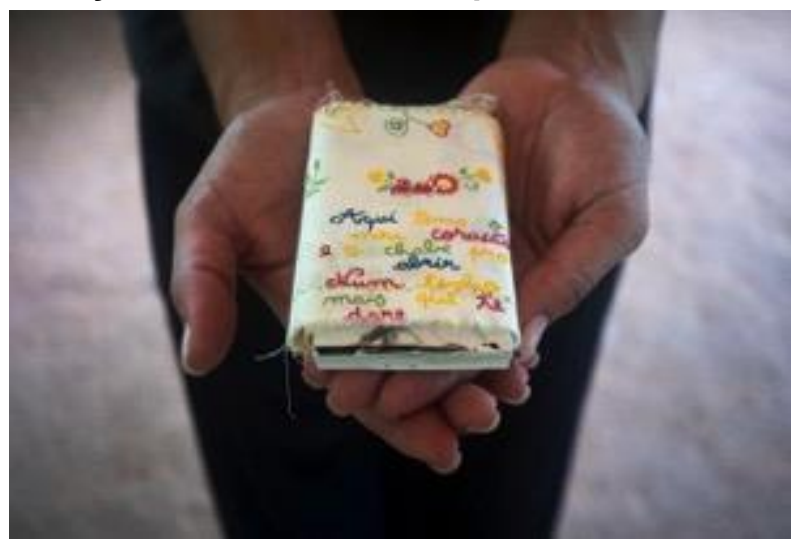

Fonte: Fotografia de Aya Saito Mira.

Figura 23 - Partilha dos cartões de Visita com a comunidade Munduruku

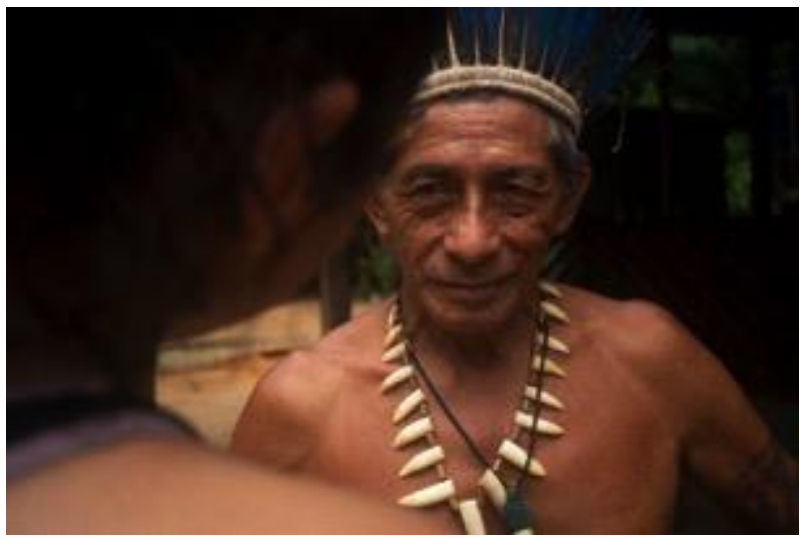

Fonte: Fotografia de Aya Saito Mira. 


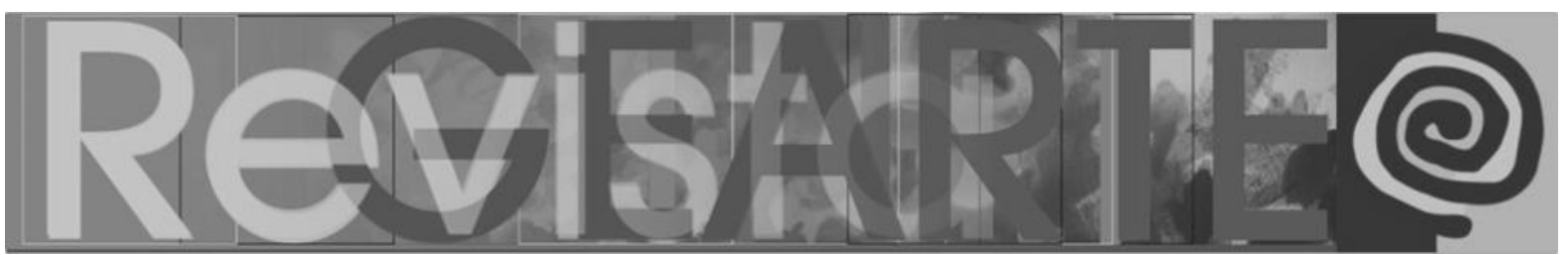

Figura 24 - Doação simbólica ao Cacique Domingos

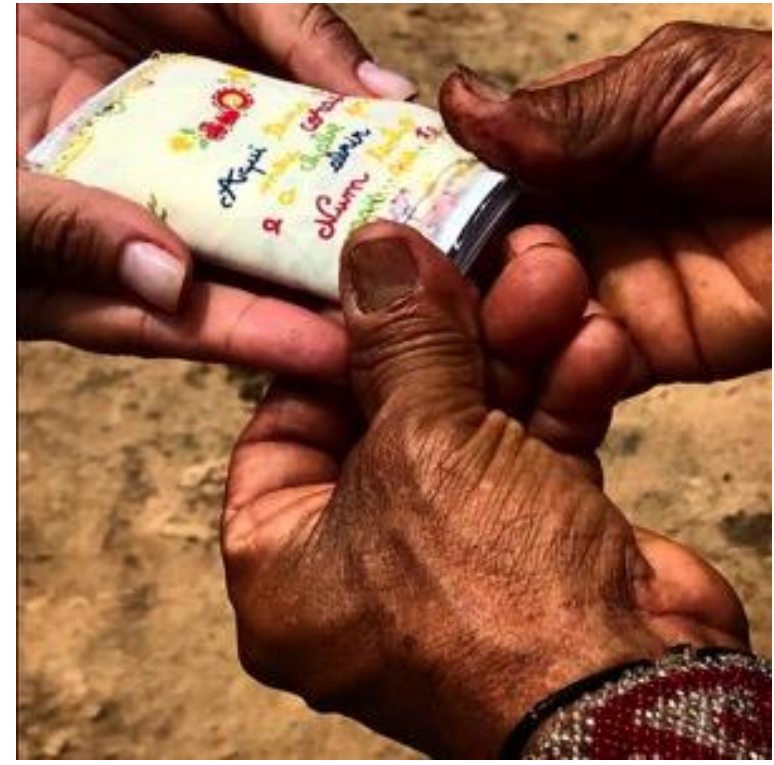

Fonte: Fotografia de Aya Saito Mira.

Figura 25 - Os cartões de visita foram partilhados e deixados, pela iniciativa do Cacique Domingos, na capela da comunidade, para que todos possam ter acesso à aliança realizada

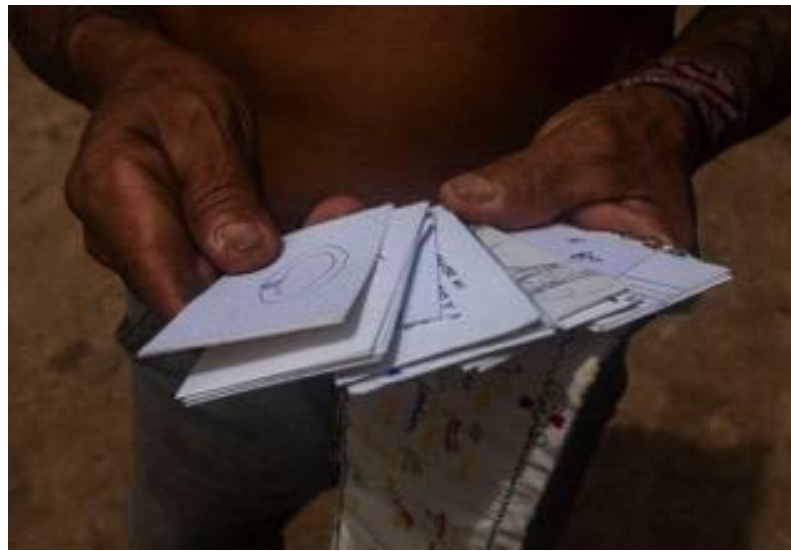

Fonte: Fotografia de Aya Saito Mira.

O encontro com a comunidade, efetivamente envolvida na partilha dos deveres sociais, revelou-nos, nas suas partilhas, capacidades desenvolvidas desde os primórdios da humanidade, que não nos podem deixar indiferentes no ensino formal das Artes Visuais, que estamos habituados nas cidades capitalistas, como por exemplo:

- A utilização do desenho como ferramenta diária de comunicação e brincadeira;

- A capacidade inventiva, através da observação do entorno; 


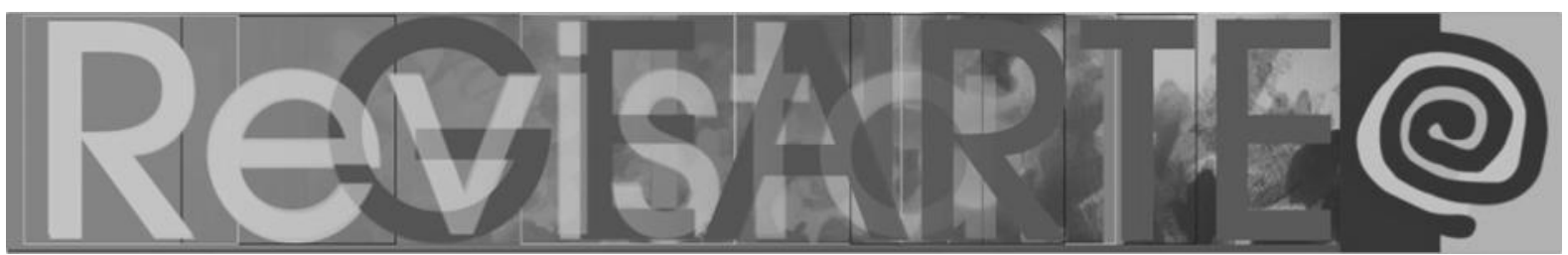

- O desenvolvimento criativo, através dos contos, da contemplação da natureza, das sombras, dos sons, dos rituais...

- O desenvolvimento sensorial, pela riqueza e diversidade da fauna, flora, clima, rio...

- A utilização do corpo desperto, que se adapta e recria juntamente com a natureza;

- A criação de objetos simbólicos, que contam histórias, transformam medos e desenvolvem capacidades de autossuperação;

- As pinturas corporais simbólicas, realizadas diariamente, obrigando ao autoconhecimento e à construção de objetivos individuais;

- A consciência da transdisciplinaridade da arte;

- O emprego sustentável dos materiais do entorno e o cuidado pela regeneração ambiental.

Figura 26 - Desenho realizado na terra, pelas crianças da aldeia, como resposta aos cartões de visita



Fonte: Fotografia das autoras. 


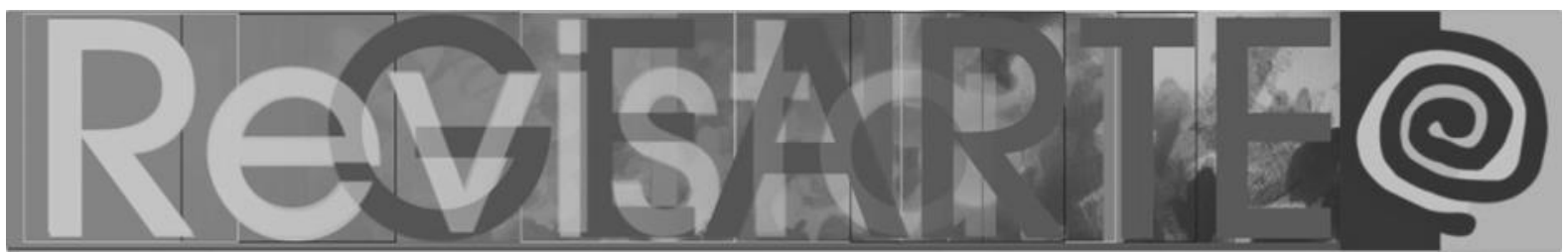

Figura 27 - Desenho realizado na terra, pelas crianças da aldeia, como resposta aos cartões de visita



Fonte: Fotografia das autoras.

Figura 28 - Desenho realizado na terra, pelas crianças da aldeia, como resposta aos cartões de visita

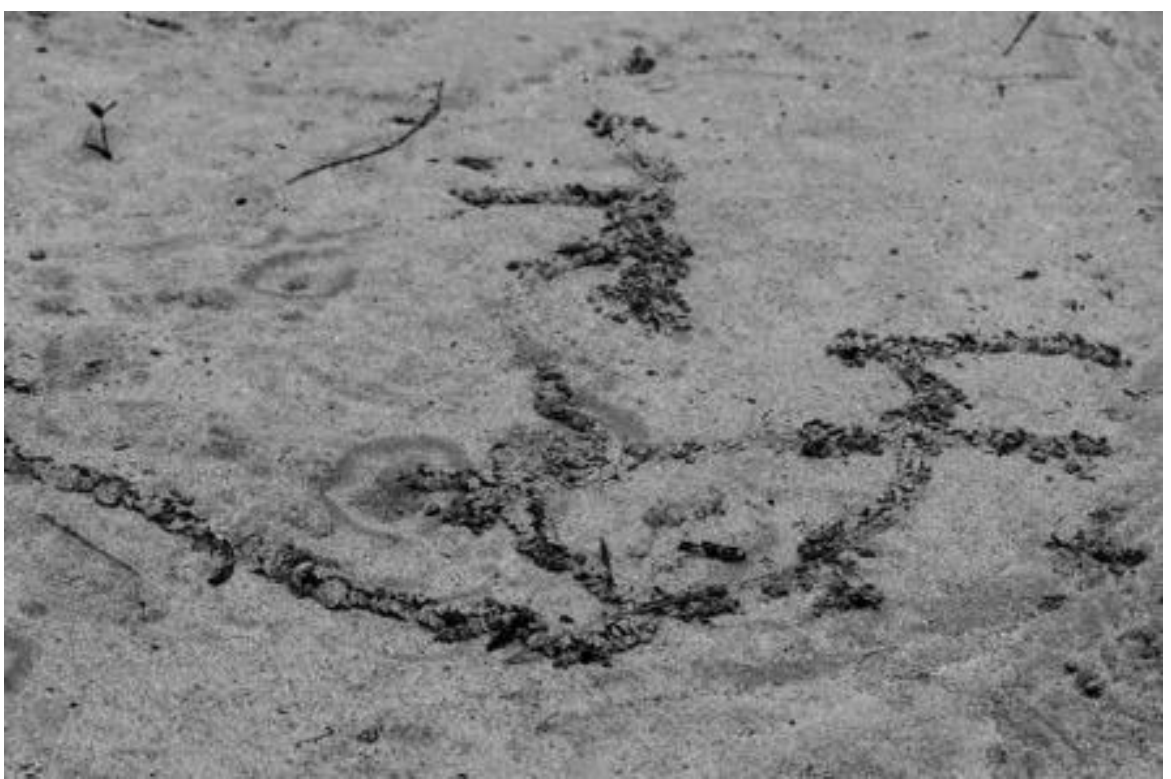

Fonte: Fotografia das autoras. 


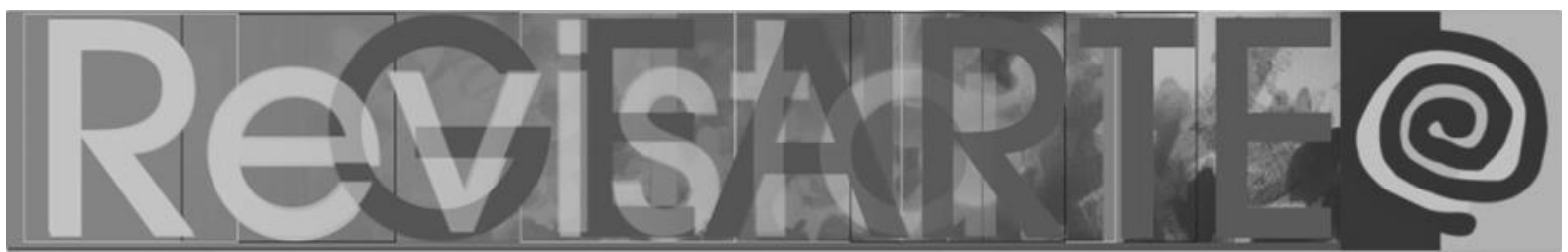

Figura 29 - Marcas deixadas nas seringadeiras depois de retirar o látex para construção de peças

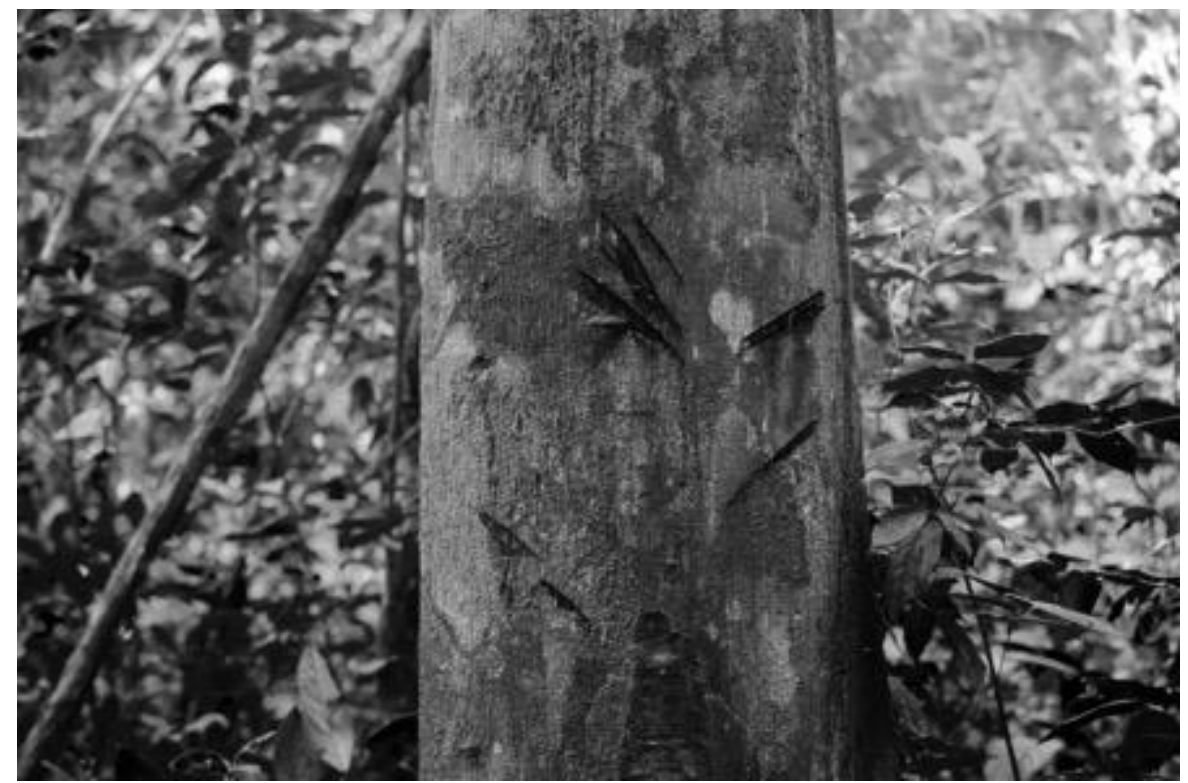

Fonte: Fotografia das autoras.

Figura 30 - Banco da aldeia realizado com troncos de árvores caídas

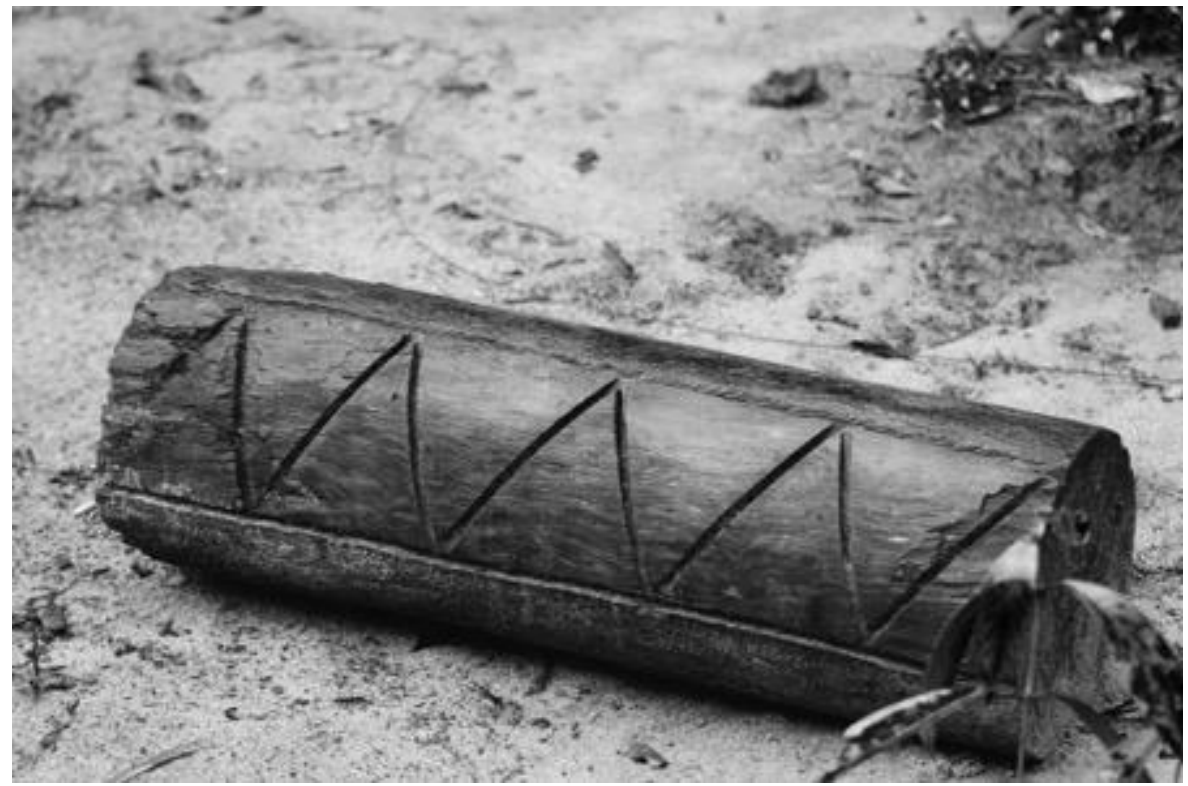

Fonte: Fotografia das autoras. 


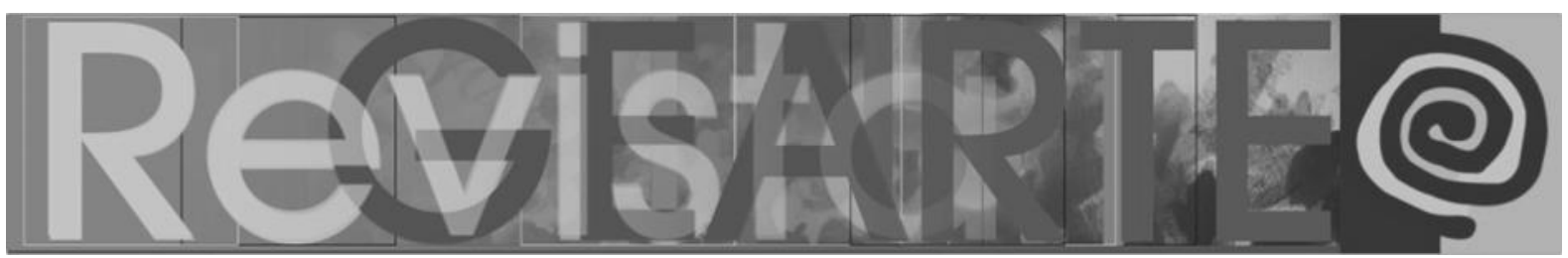

Figura 31 - Desenho realizado na terra, pelos insetos

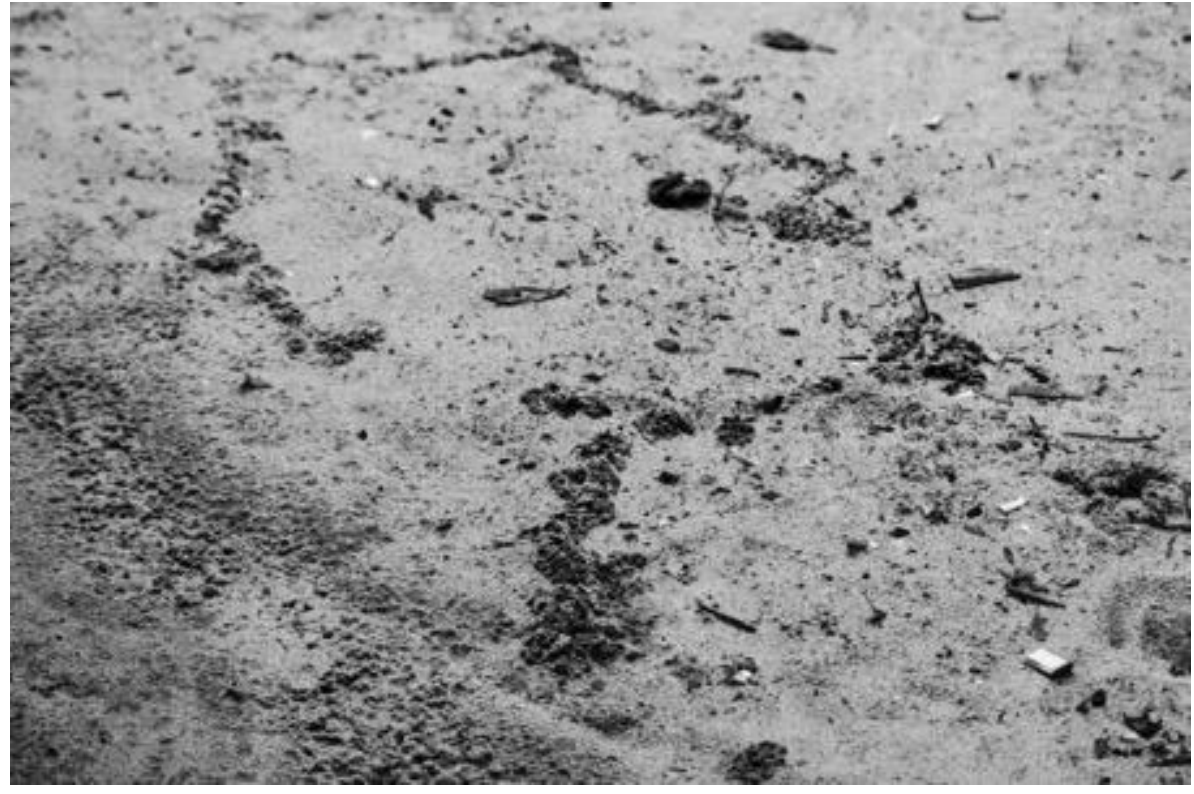

Fonte: Fotografia das autoras.

Figura 32 - Desenho realizado na terra, pelas crianças da aldeia, como resposta aos cartões de visita

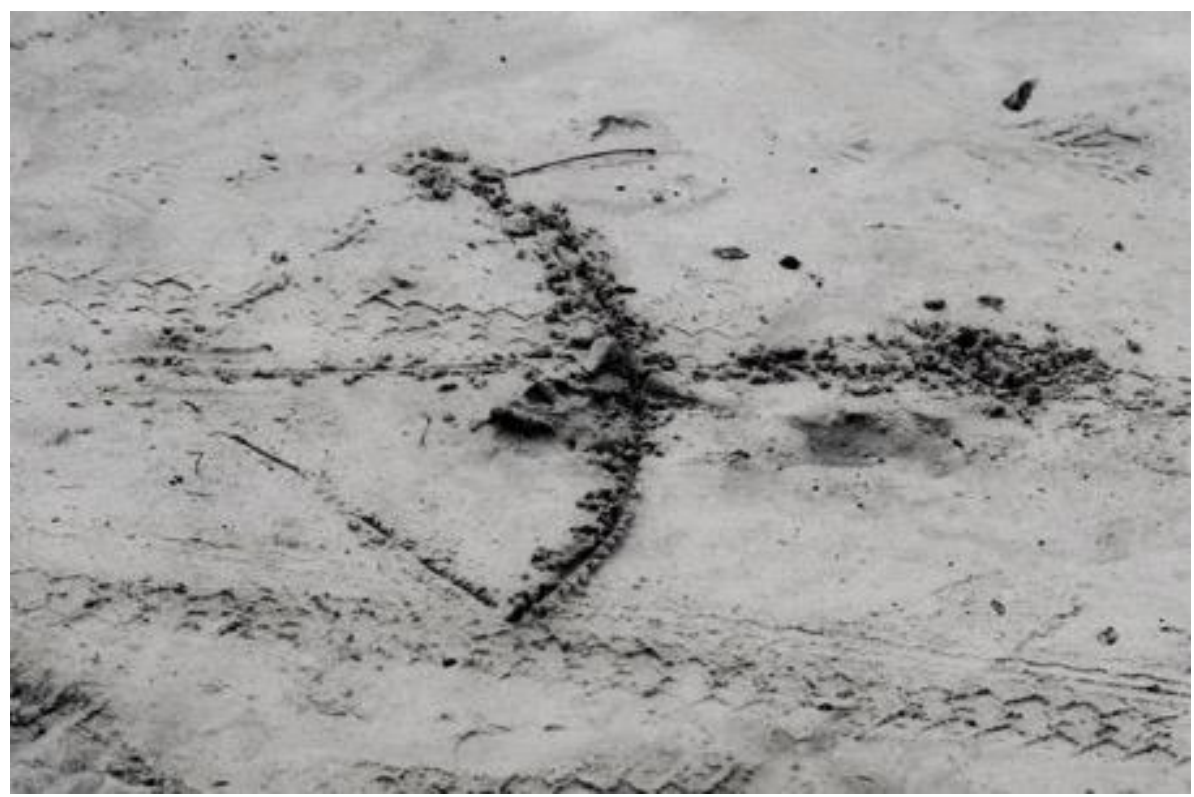

Fonte: Fotografia das autoras. 


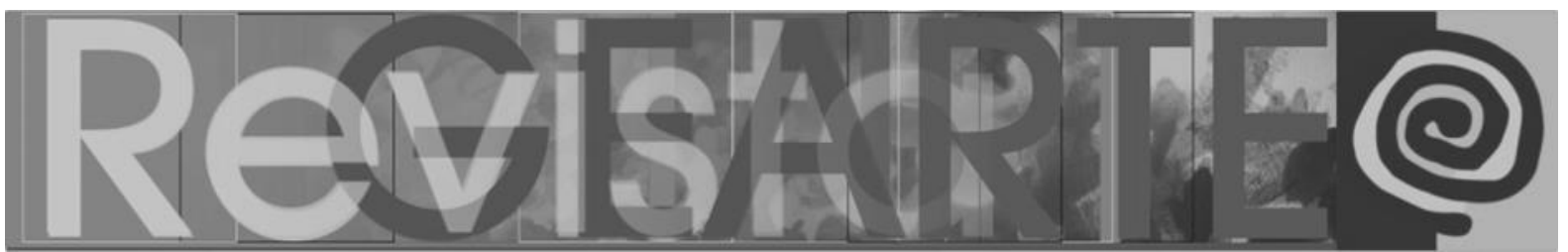

Figura 33 - Pinturas corporais

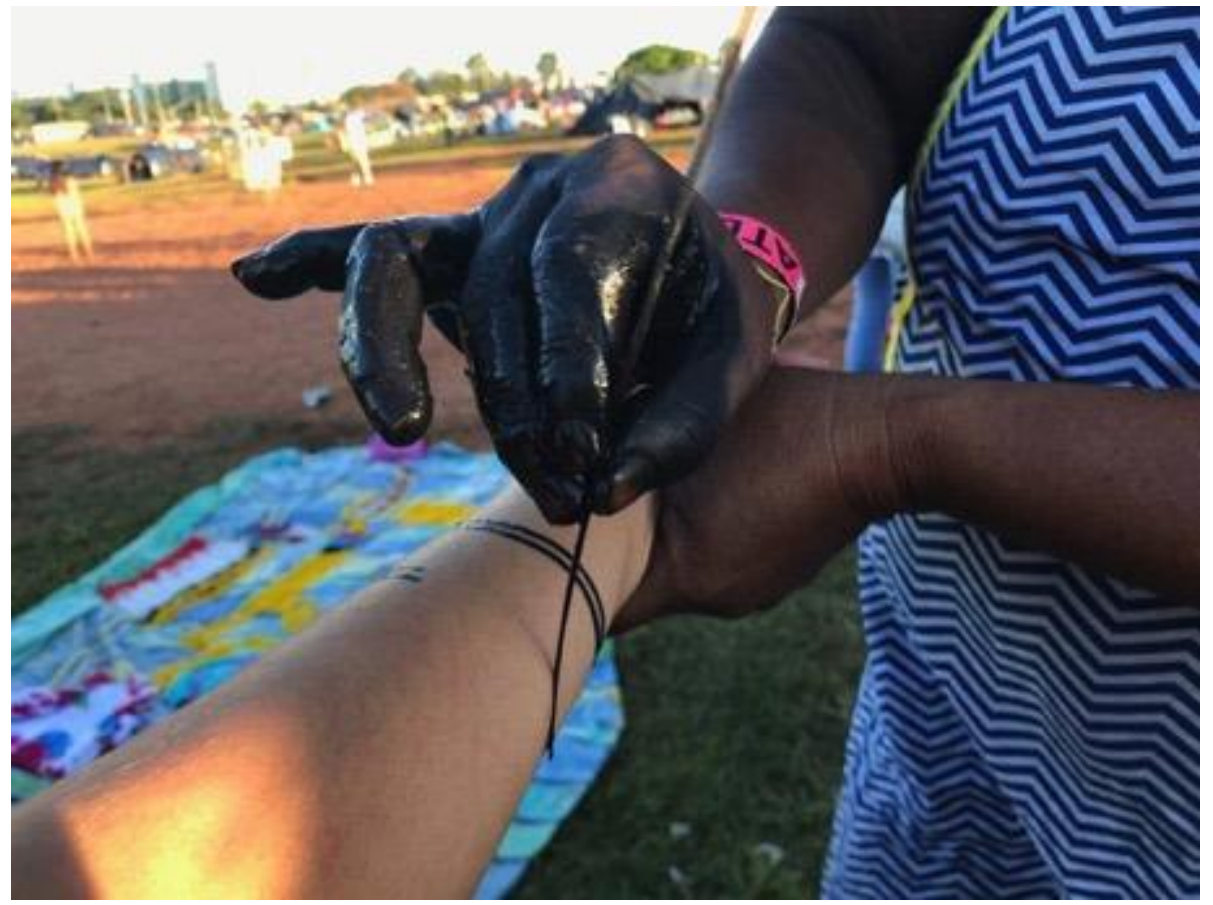

Fonte: Fotografia das autoras.

Práticas empíricas que nos fazem compreender os exercícios realizados desde sempre, na sua notória transdisciplinaridade e o seu sucesso para a construção de uma comunidade sustentável, harmoniosa e desenvolvida na criatividade, imaginação e conhecimento holístico.

\section{Nigéria (África)}

Em Maio/Junho de 2019, uma das autoras deste artigo, viajou até a Nigéria, no coração de África, para uma partilha de experiências com artistas e estudantes locais. Partindo dos mesmos objetivos das últimas viagens mencionadas transdisciplinaridade, o Ser Humano holístico, as relações, a deambulação como prática estética (CARERI, 2014), a Deriva (DEBORD, 1952), a partilha de experiências, o ensino com base nas técnicas utilizadas nas Artes Visuais e a construção de atividades no/com o lugar - realizaram-se aulas, em contexto de educação formal, em várias escolas do país. 


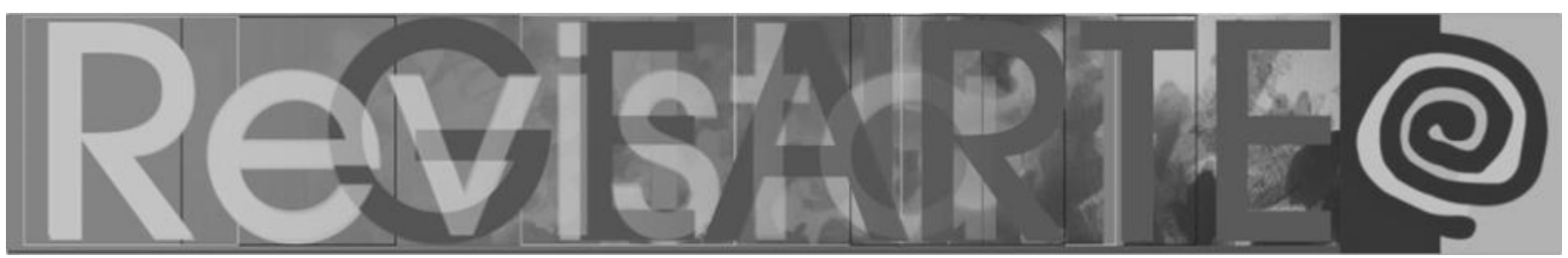

Neste artigo, iremos apresentar só uma das experiências, por considerarmos a mais pertinente para os assuntos indicados, realizada numa escola de ensino particular da cidade de Lagos.

$\mathrm{Na}$ opinião da autora, os diferentes camadas económicos visíveis na sociedade (dois extremos: ricos e pobres), relevam a imensa incapacidade (sentida pela maioria) de contacto com o exterior do país, sendo visível a sua curiosidade pelas diferentes culturas. Sendo esta a divisa para a construção e partilha de experiências.

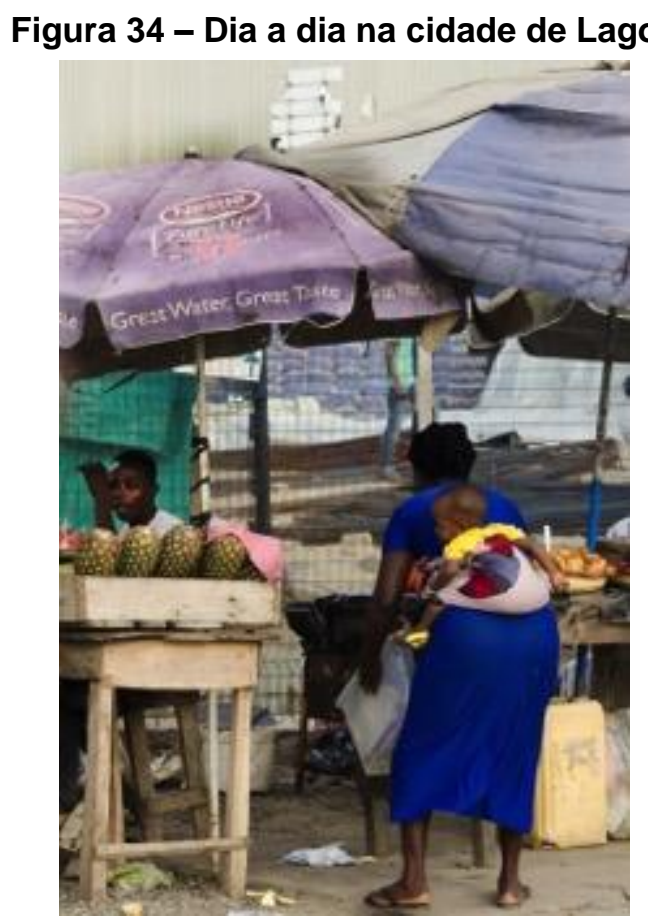

Fonte: Fotografia das autoras. 


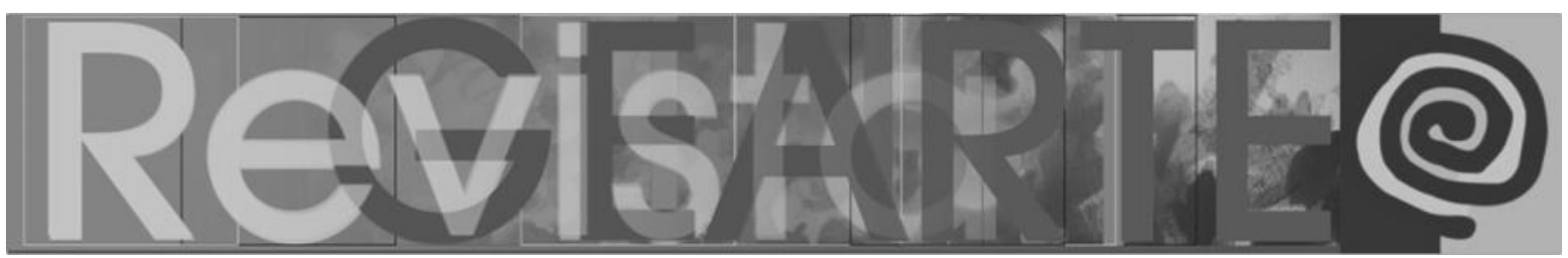

Figura 35 - Dia a dia na cidade de Lagos

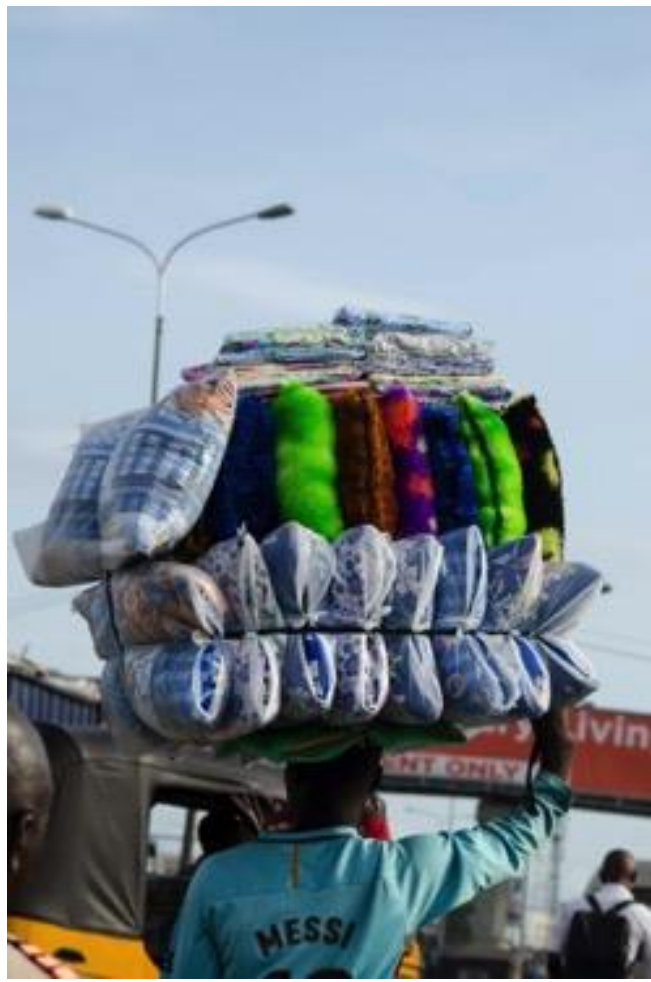

Fonte: Fotografia das autoras.

\section{Figura 36 - Dia a dia na cidade de Lagos}

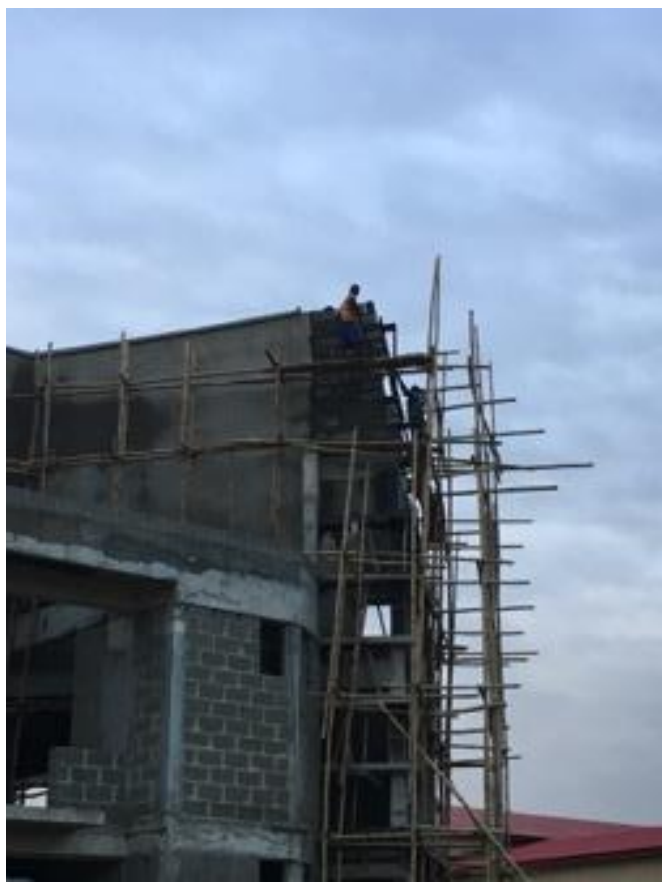

Fonte: Fotografia das autoras. 


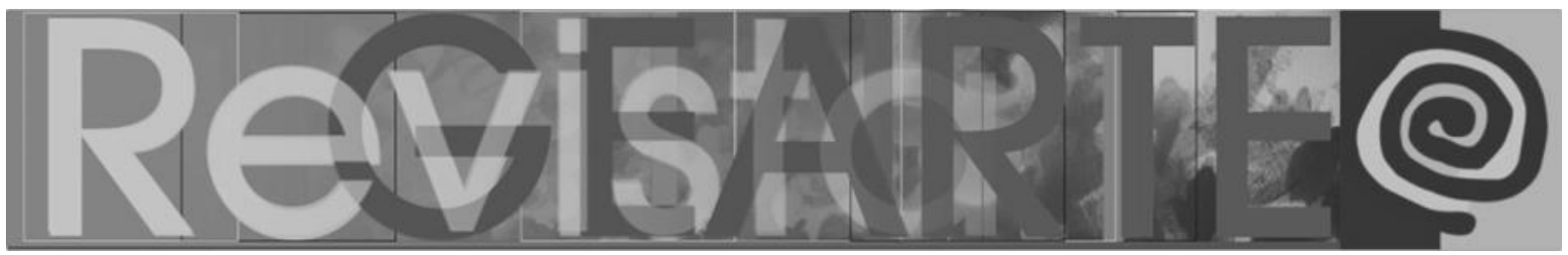

Alunos dos 12 aos 15 anos tiveram aulas-oficina que decorreram de acordo com os seus interesses nas artes visuais, com a utilização de várias técnicas, que vão desde a escrita criativa, ao desenho, pintura, fotografia, instalação ou performance. Apropriações de técnicas que respondiam à sua sede de conhecer, experimentar e partilhar.

A autora deste artigo, que dinamizou as atividades, levou consigo fotografias impressas, de algumas viagens que realizou, para iniciar a conversa, o que potenciou a proposta, por parte dos participantes, da realização, durante a Semana Internacional da Educação Artística (última semana de maio), de um atelier aberto a toda a comunidade educativa.

No Atelier Aberto a liberdade de expressão e a transitoriedade dos participantes deu origem a uma obra coletiva, realizada por alunos, professores, pais, artistas locais convidados e por todos os que por ali passaram e que quiseram colaborar.

Figura 37 - Partilhas em aula de Artes Visuais - conversas sobre o mundo e o conceito de Viagem

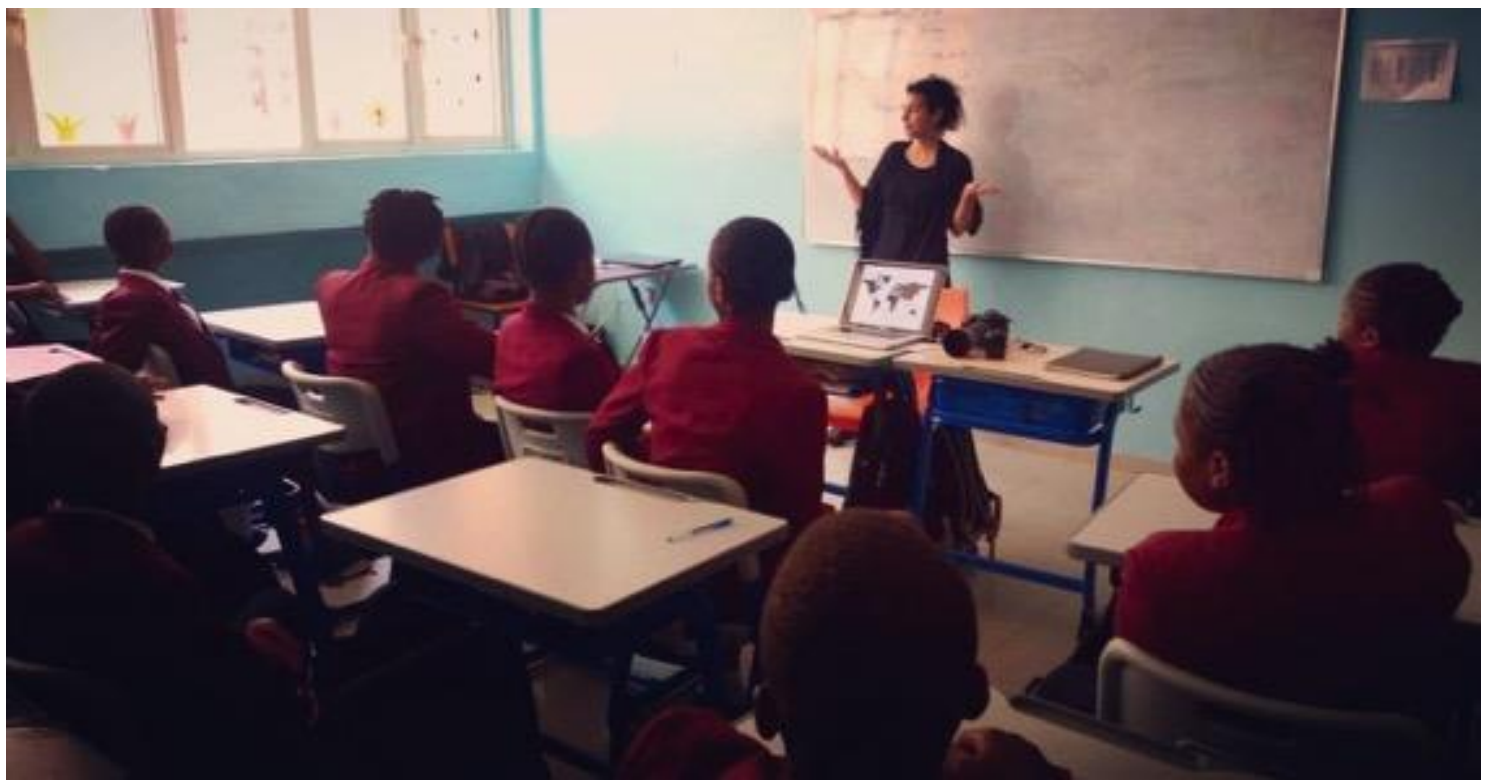

Fonte: Fotografia de Olusegun Adeniyi. 




Figura 38 - Inauguração do Atelier Aberto



Fonte: Fotografia de Olusegun Adeniyi.

Figura 39 - Exemplo de pintura realizada no Atelier Aberto

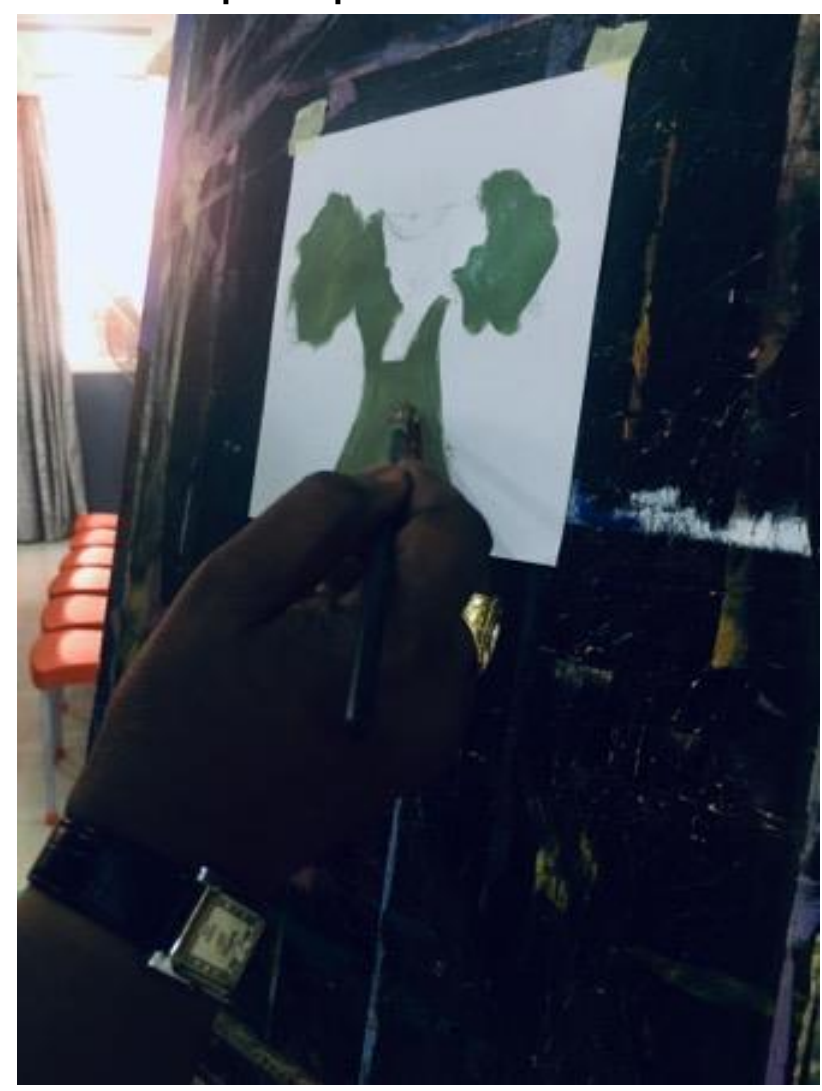

Fonte: Fotografia das autoras. 


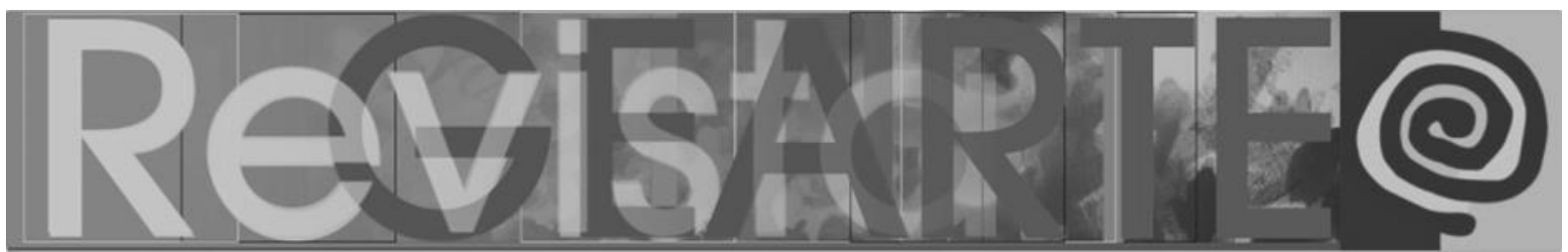

Figura 40 - Atelier Aberto, Semana Internacional da Educação Artística, com o envolvimento dos pais

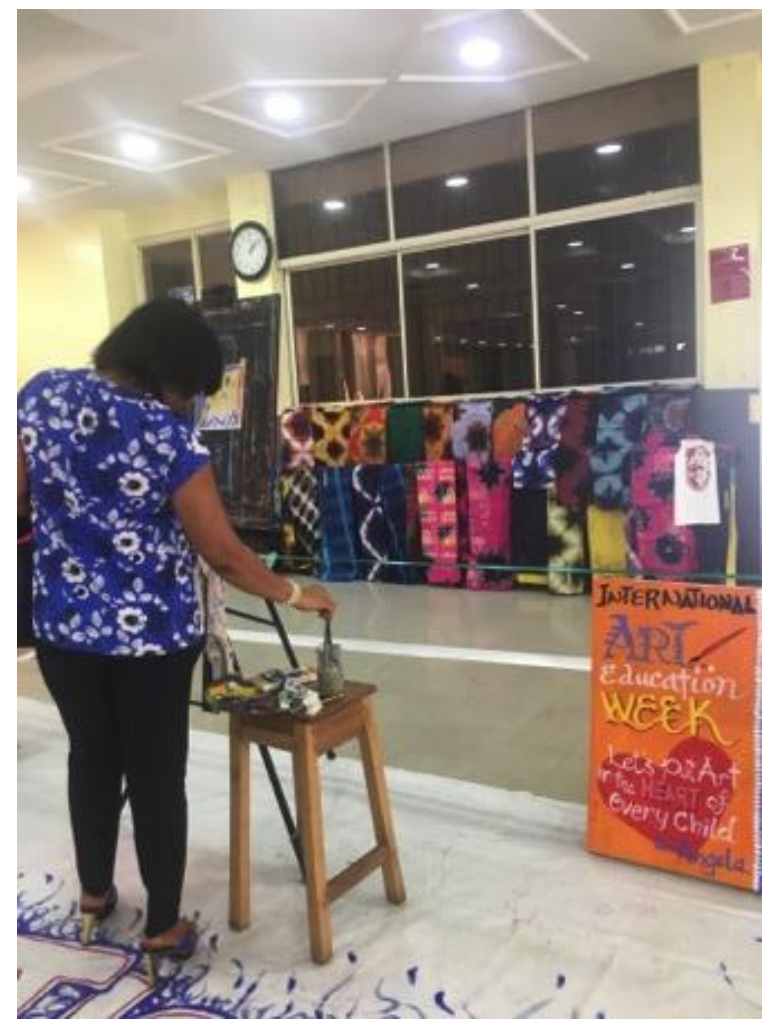

Fonte: Fotografia das autoras.

Neste contexto desenvolvemos diversas capacidades, das quais destacamos:

- A partilha de experiências;

- A autonomia e criação de um espaço ao outro;

- A dinamização de atividades para faixas etárias;

- A capacidade de compreender a diversidade das Artes;

- A necessidade de expressão com a utilização de várias linguagens;

- A compreensão de que a errância e o erro têm pontos em comum;

- A descoberta de novos vínculos nas artes;

- A compreensão de outras culturas através da imagem. 


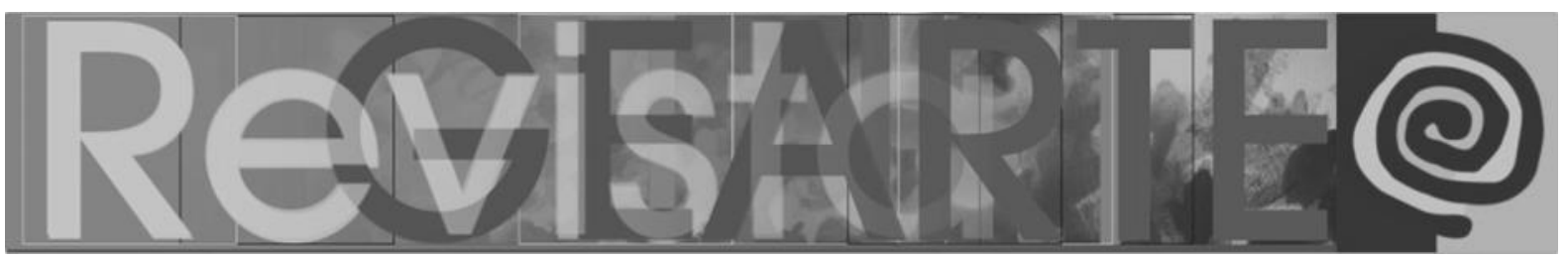

\section{Deambulações}

Os diferentes caminhos que traçamos estão recheados de partilhas, muitas delas, que não são passiveis de transmissão num artigo deste tipo. São espaços simbólicos de ação, de conhecimento e de ligação, reconhecidos nas obras de arte contemporâneas.

As autoras deste artigo, prepararam todas as ações com a utilização de metodologias artísticas diversificadas, maioritariamente centradas nas Walking Pedagogies e arte colaborativa, que defendem a democracia de escolhas e a construção coletiva de obras/práticas. Estas ações são desenvolvidas no meio em que ocorrem, com total abertura às experiências e necessidades do coletivo, sem diretrizes rígidas ou caminhos totalmente definidos. Conceitos de Obra Aberta (ECO, 2016) ou Inacabada, onde todas as interpretações ou criações são possíveis. Dando ênfase ao processo e à obra coautoral.

As ações foram realizadas sem diferenciação de pares, onde a partilha de experiências decorreu de forma ampla e interdisciplinar, com respeito cultural, com a utilização de ferramentas inerentes ao meio e negociadas entre todos os participantes e objetivos construídos no coletivo.

A amplitude das ações revelou as necessidades inerentes ao Humano: de afeto; conhecimento do outro; reconhecimento; emancipação; consciência da diversidade cultural; partilha de experiências; criação coletiva; sentimento de pertença; democracia; consciência do valor das aprendizagens individuais; reivindicação de lugares; sustentabilidade ambiental; a importância do erro e da expressão livre; a necessidade de sentir o lugar e intervir nele; a possibilidade de se perder; a consciência que a criação pode ser realizada em qualquer lugar e com os meios disponíveis; encontrar-se no mundo e no outro.

Defendemos, com as experiências que realizamos, que o ensino das Artes Visuais pode ser utilizado de forma transdisciplinar, com recurso às técnicas da 


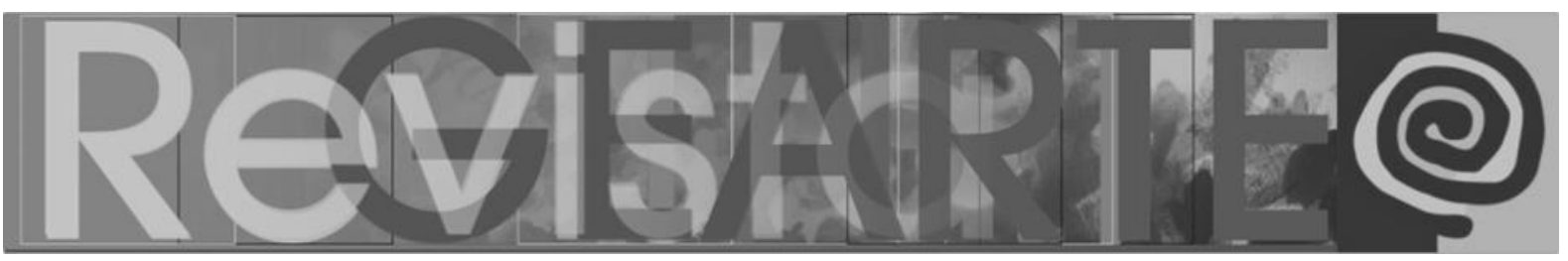

Arte contemporânea, no desenvolvimento de relações afetivas, pacíficas, de compreensão do outro e aprendizagem partilhada.

\section{Errare humanum est...}

\section{Referências}

BARROS, Manoel de. Poesia completa. Lisboa: Relógio D’Água, 2016.

BRETON, André. Manifeste du Surréalisme. Paris: Gallimard, 1924.

CAMPOS, Álvaro. Antologia poética: poemas escolhidos. Lisboa: Bertrand, 2016.

CARERI, Francesco. Walkscapes: o caminhar como prática estética. São Paulo: Gustavo Gili, 2013.

DEBORD, Guy. Introduction à une critique de la géographie urbaine. Les Lèvres Nues, Antuérpia, n. 6, 1955.

DEBORD, Guy. Théorie de la dérive. Les Lèvres Nues, Antuérpia, n. 9, 1956.

ECO, Umberto. Obra aberta. Lisboa: Relógio D’Água, 2016.

MOURÃO, Rui. Ensaio de artivismo. Lisboa: Museu Nacional de Arte Contemporânea do Chiado, 2014.

SALDANHA, Ângela; PARDIÑAS, Maria J.; EÇA, Teresa; TRIGO, Cristina. (Eds.). Risks and Opportunities for Visual Art Education. In: Europe. ed. 1, ISBN: 978-989-99073-2-4. Lisboa: APECV, 2015.

SMITH, Keri. The wander society. New York: Penguin Books, 2016.

\section{Ângela Saldanha}

Doutora em Educação Artística pela Faculdade de Belas Artes da Universidade do Porto, Mestre em Artes Visuais e Licenciada em Design pela Universidade de Aveiro. Realizou dois pósdoutoramentos em Média Arte Digital como investigadora do Centro de Investigação em Artes e Comunicação, no polo da Universidade Aberta, onde também lecionou. Doutoranda em Arte Contemporânea no Colégio das Artes, Universidade de Coimbra. Tem diversas formações acadêmicas na área da multimídia, cerâmica e produção artística contemporânea. Enquanto artista, expõe os seus trabalhos constantemente, em nível nacional e internacional. Normalmente trabalha em obras de teor ativista, de envolvimento comunitário e de reflexão crítica sobre a sociedade. Integra os coletivos: "C3" (grupo de ação e investigação em práticas artísticas interdisciplinares em Educação Artística), "1686" e "Ai ia" (pensamentos e ações artísticas). É vice-presidente da Associação de Professores de Expressão e Comunicação Visual (APECV) e membro do Conselho Europeu da International Society for Education through Art (InSEA).

Orcid: http://orcid.org/0000-0003-0404-0088

E-mail: correio@angelasaldanha.com

Currículo: https://ciac.pt/pt/quem-somos/equipa/angela-saldanha 


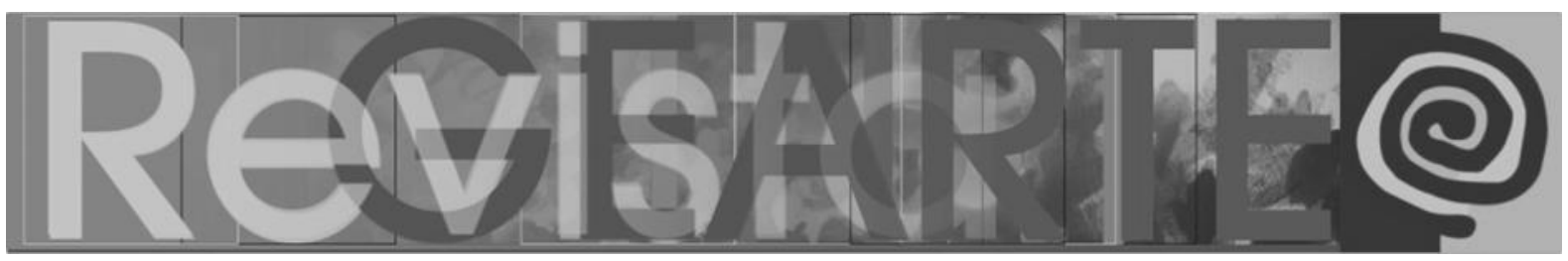

\section{Teresa Torres de Eça}

Artista Plástica e Professora de Artes Visuais. Doutora pela Universidade de Surrey Roehampton (UK). Presidente da International Society for Education Through Art - InSEA entre 2014 e 2019; Presidente da Associação de Professores de Expressão e Comunicação Visual - APECV desde 2008; Diretora do Centro de Formação de Professores Almada Negreiros (APECV); Artista Plástica e Professora de Artes Visuais na Escola Secundária Alves Martins. Colabora com o Centro de Investigação em Artes e Comunicação (CIAC) - Universidade Aberta, Portugal.Tem coordenado projetos internacionais de Educação intercultural, Educação para o desenvolvimento sustentável, Educação para a Paz, e Artivismo, Membro do grupo de investigação através das artes: C3. Editou vários livros e escreveu vários artigos em revistas internacionais sobre educação artística. É coeditora das E-publicações IMAG (InSEA Emagazine) e revista Ibero-Americana de Pesquisa em Educação, Cultura e Artes -Invisibilidades.

Orcid: https://orcid.org/0000-0002-0124-7377

E-mail: teresatorreseca@gmail.com

Currículo: https://ciac.pt/pt/quem-somos/equipa/teresa-torres-de-eca

Recebido em 1 de março de 2020 Aceito em 17 de maio de 2020 